\title{
Heterogeneity of Colorectal Cancer Progression: Molecular Gas and Brakes
}

\author{
Federica Gaiani ${ }^{1,2}{ }^{(\mathbb{D}}$, Federica Marchesi ${ }^{3,4}$, Francesca Negri ${ }^{5}{ }^{(\mathbb{C}}$, Luana Greco ${ }^{6}$, Alberto Malesci ${ }^{3,7}$, \\ Gian Luigi de' Angelis ${ }^{1,2}$ and Luigi Laghi $1,6, *$ (1)
}

1 Department of Medicine and Surgery, University of Parma, 43126 Parma, Italy; federica.gaiani@unipr.it (F.G.); gianluigi.deangelis@unipr.it (G.L.d.)

2 Gastroenterology and Endoscopy Unit, University-Hospital of Parma, via Gramsci 14, 43126 Parma, Italy

3 IRCCS Humanitas Research Hospital, via Manzoni 56, 20089 Rozzano, Italy; federica.marchesi@humanitasresearch.it (F.M.); alberto.malesci@hunimed.eu (A.M.)

4 Department of Medical Biotechnology and Translational Medicine, University of Milan, 20132 Milan, Italy

5 Medical Oncology Unit, University Hospital of Parma, 43126 Parma, Italy; fnegri@ao.pr.it

6 Laboratory of Molecular Gastroenterology, IRCCS Humanitas Research Hospital, via Manzoni 56, 20089 Rozzano, Italy; luana.greco@humanitasresearch.it

7 Department of Biomedical Sciences, Humanitas University, Via Rita Levi Montalcini 4, 20072 Pieve Emanuele, Italy

* Correspondence: luigi.laghi@humanitas.it

Citation: Gaiani, F.; Marchesi, F.;

Negri, F.; Greco, L.; Malesci, A.;

de'Angelis, G.L.; Laghi, L.

Heterogeneity of Colorectal Cancer

Progression: Molecular Gas and

Brakes. Int. J. Mol. Sci. 2021, 22, 5246.

https://doi.org/10.3390/ijms22105246

Academic Editor: Luba Hunáková

Received: 22 April 2021

Accepted: 13 May 2021

Published: 15 May 2021

Publisher's Note: MDPI stays neutral with regard to jurisdictional claims in published maps and institutional affiliations.

Copyright: (c) 2021 by the authors. Licensee MDPI, Basel, Switzerland. This article is an open access article distributed under the terms and conditions of the Creative Commons Attribution (CC BY) license (https:// creativecommons.org/licenses/by/ $4.0 /)$

\begin{abstract}
The review begins with molecular genetics, which hit the field unveiling the involvement of oncogenes and tumor suppressor genes in the pathogenesis of colorectal cancer (CRC) and uncovering genetic predispositions. Then the notion of molecular phenotypes with different clinical behaviors was introduced and translated in the clinical arena, paving the way to next-generation sequencing that captured previously unrecognized heterogeneity. Among other molecular regulators of CRC progression, the extent of host immune response within the tumor micro-environment has a critical position. Translational sciences deeply investigated the field, accelerating the pace toward clinical transition, due to its strong association with outcomes. While the perturbation of gut homeostasis occurring in inflammatory bowel diseases can fuel carcinogenesis, micronutrients like vitamin D and calcium can act as brakes, and we discuss underlying molecular mechanisms. Among the components of gut microbiota, Fusobacterium nucleatum is over-represented in CRC, and may worsen patient outcome. However, any translational knowledge tracing the multifaceted evolution of CRC should be interpreted according to the prognostic and predictive frame of the TNM-staging system in a perspective of clinical actionability. Eventually, we examine challenges and promises of pharmacological interventions aimed to restrain disease progression at different disease stages.
\end{abstract}

Keywords: colorectal cancer; progression; heterogeneity

\section{Heterogeneous Gene Damage and Different Progression of Colorectal Cancer The Discovery of the Main Patterns of Gene Damage, CIN and MSI}

More than three decades ago, molecular genetics introduced a substantial revolution in oncology. The discovery of the derangements due to the activation of oncogenes and the silencing of tumor suppressor genes put forward the notion that the type and amount of genetic damage underlie the development and the evolution of cancer. In the beginning, hunting for genes responsible for inherited predispositions to cancer had a pivotal role, and colorectal cancer (CRC) acted as a key model. The discovery that APC was the gene underlying the development of familial polyposis (FAP), once mutated in the germline [1-3], fit the two-hit hypothesis by Knudson [4] in light of somatic inactivation of the other allele in somatic tumor cells [5], mostly due to loss of heterozygosity, as in the case of retinoblastoma [4]. It was also shown that the same type of gene damage occurs in most sporadic tumors, inactivating the two alleles of this gatekeeper in somatic cells 
along colorectal carcinogenesis. In the early 1990s, the main players in CRC were APC, KRAS [6] and TP53 [7,8], and a model for their mostly sequential multistep damage [9] became a paradigm in cancer genetics [10]. Meanwhile, moving from the APC-FAP lesson, researchers were trying to identify the culprit for hereditary non-polyposis colorectal cancer (HNPCC; now referred to as Lynch syndrome) [11,12]. Independent teams contributed to the discovery of the molecular phenotype of this disease, known as microsatellite instability (MSI), although the initial terminology differed according to the groups engaged in the competitive discovery [13-15]. It became rapidly appreciated that Lynch syndrome and MSI arose because of germline defects in one of the genes of the DNA mismatch repair (MMR) system (namely MLH1, MSH2, MSH6, PMS2 and EPCAM deletion) [16]. Additionally, MSI observed in a relevant fraction of sporadic CRCs $(\geq 10 \%)$ was short after being linked to somatic silencing of $M L H 1$, due to its promoter hypermethylation [17-19]. Altogether, MSI inherited and sporadic cancers account for $15-20 \%$ of CRCs, and their somatic damage is different from that of non-MSI CRCs (or MS-stable, MSS). MSI cancers harbor thousands of unrepaired replication errors, mostly frameshift mutations not observed in MSS tumors, which otherwise display much higher degrees of chromosomal damage (from rearrangements to aneuploidy), and were thus also termed chromosomally unstable or CIN (Table 1). The growing importance of understanding that a molecular classification of CRC could be attained is exemplified by the appearance of the feasibility of a molecular screening that could allow distinguishing MSI from MSS CRCs at end of the 1990s [20]. Surprisingly, clinical actionability of such molecular differentiation, although well established, was unanimously recognized by scientific societies active in the clinical arena 15 years later [21] Expanding the lessons learned from inherited predispositions, the molecular heterogeneity of CRC was becoming apparent, spreading the notion that this disease encompasses entities with different progression (i.e., natural history) and postsurgical evolution [22]. Clinically, it became increasingly appreciated that MSI cancers display a significant better postsurgical outcome, largely explained by the low rate of patients presenting with advanced disease at diagnosis, due to their reduced metastatic potential [23-25]. MSI and CIN cancers were also differentiated according to the responsiveness to cytotoxic chemotherapy [26], thus anticipating the notion that the type of genetic damage may modify the responsiveness to drugs as well [27], and later it was shown that defective MMR is a predictive marker for lack of efficacy of fluorouracil-based adjuvant therapy in CRC [28].

Table 1. Molecular phenotypes of colorectal cancer according to the prevalent patterns of alterations.

\begin{tabular}{|c|c|c|c|}
\hline \multicolumn{2}{|c|}{ DNA } & \multicolumn{2}{|c|}{ mRNA } \\
\hline Type of Gene Damage & Methylation & \multicolumn{2}{|c|}{ Gene Expression Patterns } \\
\hline $\begin{aligned} & \text { Microsatellite instability (MSI) } \\
= & \text { mismatch repair }(\text { MMR) deficient }\end{aligned}$ & CpG island methylator (CIMP+) & \multicolumn{2}{|c|}{$\begin{array}{c}\text { Consensus molecular subtype (CMS) } 1 \\
\text { CRC intrinsic subtype (CRIS)-A/B }\end{array}$} \\
\hline \multirow{3}{*}{$\begin{array}{c}\text { Microsatellite stable (MSS) } \\
=\text { MMR proficient } \\
=\text { chromosomal instability (CIN) }\end{array}$} & \multirow{3}{*}{ Mostly CIMP- } & CMS2, canonical & CRIS-C \\
\hline & & CMS3, metabolic & CRIS-D \\
\hline & & CMS4, mesenchymal & CRIS-E/B \\
\hline
\end{tabular}

More recently, the responsiveness of progressive metastatic CRC to immune checkpoint blockade (anti-programmed death 1 immune check point inhibitor) was shown to occur more frequently in patients with MMR-deficient cancers (harboring an average of 1782 somatic mutations; see below) than in MMR-proficient cancers (harboring a mean of 73 mutations) [29].

Thus, molecular data over time have established the bases for the notion that different types of genetic damage underlie different natural histories of CRC progression, as well as its postsurgical outcome and drug-responsiveness. 


\section{DNA Hypermethylation and CIMP}

As the clinical-pathological differences between MSI and MSS CRCs were becoming increasingly evident, a further molecular subtype was being investigated. Moving from the methylation status of MLH1 in sporadic MSI CRCs [30], it was appreciated that gene hypermethylation events cluster in a fraction of cases, overlapping with sporadic MSI [31] ones due to MLH1 hypermethylation. The comparison of the increased frequency of epigenetic events at certain loci (although these were not as well standardized as those tested to establish MS-status) coincided with the proposal of a third CRC molecular subtype, referred to as $\mathrm{CpG}$ island methylator phenotype, or CIMP [32,33] (Table 1). Promoter hypermethylation leading to gene silencing would thus resemble other gene-silencing mechanisms, and also can occur as a second hit in genes like APC [34]. Similar to MS typing, the CIMP profile obtained by the analysis of given loci allows differentiating CRC accordingly (i.e., CIMP high vs. low vs. no-CIMP). CIMP+ or high CRC had a peculiar profile [35], associated with older age, proximal location, poor differentiation, MSI-high and BRAF mutation [33], and inversely with LINE-1 hypomethylation. CIMP-high CRCs were also found to have a better outcome than CIMP-low, particularly if showing wild-type $B R A F$ [36]. The concept that was originating was that it would be eventually possible to reach a molecular pathological epidemiology of CRC exploiting molecular classification and incorporating interactions with environmental factors, as well as associations with clinical outcome [37].

\section{The Advent of Next-Generation Sequencing and the Evidence of Widespread Genetic Heterogeneity}

While these classification schemes [36] were being variably adopted in translational research [38], new sequencing technologies (i.e., next-generation sequencing, NGS) hit the research ground, allowing an unbiased identification of the extent of genetic damage in cancer [39], which was previously unthought. These innovative explorations showed that the average number of gene mutations in CRC was approximately 80, of which one out of 5-6 would occur in candidate cancer genes. It also emerged that such candidates encompassed genes for which, in spite of functional studies, no mutational evidence had been previously reported for their association with cancer, as well as genes not previously linked to neoplasia. Such candidates comprised transcriptional regulators, genes involved in cell adhesion and signal transduction. The heterogeneity of mutated genes was exemplified by the shared number of candidate cancer gene mutations, not exceeding six common mutants among cancers. These notions were refined shortly afterward by drawing the genomic landscape of CRC [40], which, when recapitulating these results, showed how a few mutational peaks (or "mountains") in known cancer genes are outnumbered by a multitude of hills represented by infrequently mutated genes. The previous focus on mountains was largely determined by available technology, while NGS introduced new paradigms. In this novel mutational milieu, a minority of the events is responsible for driving the processes of tumor initiation, progression and maintenance. The vast heterogeneity of the mutational hills occurring in individual CRC could still be recapitulated by the pathways they derange. Thus, it could be possible to classify the main alterations occurring during tumorigenesis according to the pathways targeted by mutational events. Along this line, mRNA sequencing by NGS provides a way to identify the alterations of gene expression occurring in colorectal carcinogenesis, and by mean of this approach, an international consensus was thus proposed comprising four molecular subtypes (i.e., CMS1 to CMS4) [41]. This network-based approach used aggregated expression data from six previously analyzed cohorts [41], and eventually recapitulated CRC subtypes into MSI immune (CMS1), canonical (CMS2), metabolic (CMS3) and mesenchymal (CMS4) (Table 1). This taxonomy was based upon differences in gene expression, mainly refining the classification of non-MSI subtypes. These expression patterns also reflected in individual clinical behaviors marked by different relapse-free survivals and survival after relapse. However, gene-expression patterns are influenced by their stromal content, which 
contributes to the type and quantity of detected transcripts. Isella et al. showed that this is the case for the mesenchymal subtype, and that transcriptional signatures incorporating cancer-associated fibroblasts (CAF), leukocytes or endothelial cells were more abundant in CRC classified as mesenchymal [42]. Interestingly, CRC with a high content of CAF transcripts was associated with a worse outcome, specifically in the absence of adjuvant therapy. Accordingly, an evolution of the classification employing transcriptional signatures was then developed following the depletion of the stromal signatures, which can be obtained by xeno-transplantation. This approach assessing intrinsic translational features of cancer cells led to the identification of five CRC intrinsic subtypes (CRIS; A to E), in which transcriptional signatures are inherent to neoplastic cells deprived of the stromal components [43] (Table 1). As this classification was experimentally developed by moving from CRC samples that had produced liver metastases, it might better fit aggressive tumors than those with smolder behavior. These studies testify that together with technological improvement, bioinformatics entered into the arena of molecular analysis, modifying the classic "black and white" or null hypothesis approach. Clearly, overlaps exist among the different classification schemes, and certain historically proven paradigms persist, chiefly the taxonomic independence of MSI/CIMP/BRAF-mutated tumors. Differently, the stromal contamination may affect the independence of a mesenchymal subtype, thus questioning the occurrence of epithelial to mesenchymal transition (EMT) in CRC [44]. At any event, taxonomic features like the content of CAF signatures remain a negative prognostic factor, indicating the relevant contribution exerted by the stromal compartment in determining disease progression.

Under several respects, it became progressively evident that intrinsic genetic and epigenetic features of the tumor are not the only factor that can explain the different behaviors of CRC. While the type of gene damage inherently drives the evolutive speed of cancer, other "extrinsic" processes are involved in determining its progression. Among these is the immune response of the host, comprising chiefly its adaptive immune arm [45], but not restricted to it $[46,47]$. The playgrounds for cancer restraint or fueling could be local; i.e., the tumor microenvironment (TME), as well as systemic and at distant sites, such as the metastatic niche [48].

\section{Tumor-Host Immune Response as Switcher on the Routes of Cancer Progression}

Alongside more common histopathological and molecular classifiers, recent years have witnessed the emergence of immune components as prognostic markers in CRC [45,49,50]. What is commonly referred to as the immune contexture [51]; i.e., the density and types of immune cells infiltrating cancer tissues, has been object of studies aimed at both highresolution definition (primarily achieved with multidimensional approaches) and narrowing down to specific biomarkers to be used in daily routines. The Immunoscore represents the ultimate output of those studies [52,53].

Efforts aimed at providing associative links between specific immune cell types and distinct disease outcomes set their foundations on earlier observations that most cancer tissues host immune cells in their microenvironment [54,55], and on mechanistic evidence of the involvement of immune-based circuits in cancer progression [56-60]. Particularly relevant have been studies aimed at showing the causative link between inflammation and cancer occurrence and progression $[56,60]$. On the other hand, the contribution of adaptive immunity to recognition and elimination of cancer cells has been known for a long time $[54,55]$. Both components, innate and adaptive, with their complex and intersecting protumor and antitumor capabilities clearly emerge from deep analyses of the microenvironment of CRC [61]. A balance between the two is likely to contribute to progression versus resistance.

Human studies have not allowed, so far, to mechanistically define the sequence of events that cause accumulation of specific immune subsets in cancer tissues. Despite the fact that recent high-dimensional studies have shed light on the variety of immune cells in human CRC tissues [61], fully elucidating the complex dynamics and relative contribution 
of resident versus recruited immune components requires further studies. Nonetheless, a general scenario depicting how immune cells infiltrate a tumor is represented by the cancer immune cycle [62], according to which antigen-presenting cells, mostly dendritic cells (DCs), infiltrate the tumor tissue, uptake tumor-derived products by various innate recognition receptors, produce type I interferons and traffic to draining lymph nodes, where they present antigens to antigen-specific cytotoxic $T$ cells (Figure 1). This event may be more efficient in tumors expressing neoantigens or with a high mutational burden [63]. Subsequent migration of activated $\mathrm{T}$ cells through the circulation and back to the tumor, guided by chemokine gradients including primarily CXCL9/CXCL10, would account for the high density of $\mathrm{T}$ cells in cancer tissues [64]. As to the activation status of $\mathrm{T}$ cells, prolonged immunosuppressive circuits, such as inhibitory axes like CTLA-4 and PD-1, may be responsible for T-cell dysfunction, accounting for the immune escape and cancer progression.

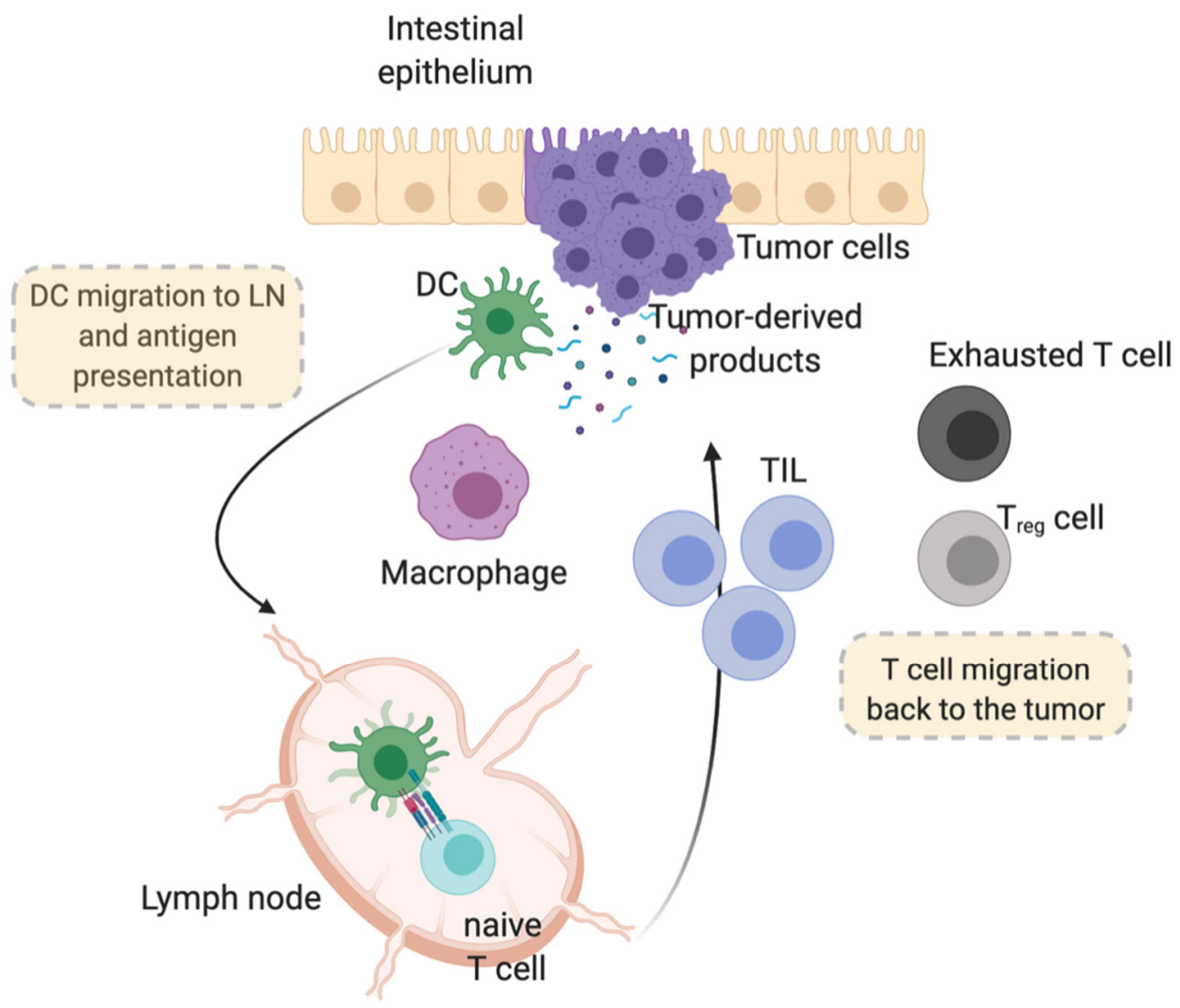

Figure 1. Scheme of the cancer immune cycle, depicting antigen-presenting cells (mostly dendritic cells, DC), which infiltrate the tumor tissue, uptake tumor-derived products and traffic to draining lymph nodes, therein presenting antigens to antigen-specific cytotoxic T cells. Sustained immunosuppressive circuits may induce T-cell dysfunction, immune escape and eventually cancer progression.

As mentioned, resident immune populations; e.g., tissue resident macrophages (TRMs) or intraepithelial lymphocytes (IELs), variably contribute to the balance of protumor or antitumor functions. Macrophages are specialized phagocytes with a high capability to ingest cellular debris, present antigens and impact on the adaptive immune response through cytokine production [65]. Their plasticity is a peculiar feature, whereby they can adopt an inflammatory phenotype ensuing in tumor elimination, as well as mature to subtypes evidently engaged in protumor functions. In the colon, TRMs have been described as constantly replenished by circulating monocytes [66]. This peculiarity that 
distinguishes them from other, long-lived TRMs may account for the exceptional favorable prognosis associated with macrophages in human CRC.

\section{Cellular and Molecular Players in the Tumor Microenvironment: Meaningful Links}

The immune microenvironment of $\mathrm{CRC}$ has gained much attention in the last few years, primarily because of the coexistence of protumor inflammatory signals and antitumor adaptive immune responses. These two almost opposite scenarios impinge into distinct clinically relevant outcomes. The link between chronic inflammation and CRC is robustly reflected in a higher risk of malignant transformation in inflammatory bowel disease (IBD) patients [60,67-70]. On the other hand, the strong capability shown by T-cell-related variables to stratify CRC patients in prognostic groups [45,49] suggests the existence of effective antitumor adaptive circuits. Translation of this knowledge to evidence-based biomarker identification is an active field and holds promise for better management of CRC patients. Both soluble mediators and cell types are being evaluated as markers of disease progression, based on mechanistic evidence of their involvement in the TME of CRC.

\subsection{Soluble Mediators}

The considerable and persistent release of inflammatory mediators in the TME is causatively linked to the strong association between IBD and CRC development $[68,71-73]$. Persistent infections $[60,74]$, as well as sterile tissue damage (leading to release of alarmins, cell-stress signals, free nucleic acids), are acknowledged as drivers of the inflammatory response, by generating molecular patterns recognized as harmful by innate inflammatory cells [58,59]. Activation of key transcription factors, such as NF-kB and STAT-3, critically induces production of inflammatory mediators, including interleukin 1 beta (IL-1 $\beta$ ), tumor necrosis factor-alpha (TNF $\alpha$ ), interleukin 6 (IL-6) and chemokines (CCL2 and CXCL8), further fueling recruitment of inflammatory leukocytes. Both cytokine mediators with a clear tumor-inhibitor effect, such as interferon-gamma (IFN-r); IL-12, 15 and 18 [73]; and a protumor one, such as IL-6, IL-17A, IL-22 and IL-23, have been recorded in CRC [73,75]. For others, such as IL-1 and TNF $\alpha$, which are master inflammatory cytokines, the role is still debated and highly dependent on the experimental setting [71]. Collectively, the divergent roles of cytokines in CRC could be explained by the coexistence of some inflammatory mediators orchestrating specific antitumor immunity [71,76] and a variety of cytokines sustaining and fueling detrimental protumorigenic inflammation. The critical contribution of these players and of other innate mediators, such as pentraxin-3 (PTX3) and C reactive protein (CRP), involved in early inflammatory circuits to the inflammatory milieu, have promoted studies aimed at testing their prognostic value in CRC [73,77-79]. Blood markers of oxidative stress have been found to be strongly associated with poor prognosis in CRC [80]. AN emerging concept is that profiling of multiple cytokines is a better approach, based on evidence that protumorigenic and antitumorigenic cytokines are found and correlate with disease outcome [76].

\subsection{Immune Cell Players}

The occurrence and clinical relevance of effector $\mathrm{T}$ cells in CRC has enjoyed a lot of attention in the last decade, due to the already-discussed translational implications $[45,49,50,81]$. In a recent study on CRC, Zhang et al. finely profiled immune subsets using a comprehensive sequencing approach and identified 20 clusters of $\mathrm{T}$ cells, of which eight were $\mathrm{CD} 8^{+}$and 12 were $\mathrm{CD} 4^{+} \mathrm{T}$ cells [82], allowing concomitant tracking of trajectories of some T-cell subsets to others. These approaches open a range of possibilities to gain more insights into immune infiltrating cells, with the potential to be translated to identification of relevant markers.

Regulatory T cells (Treg) are essential suppressive modulators of intestinal inflammation, thanks to their production of the anti-inflammatory cytokines IL-10 and transforming growth factor beta (TGF- $\beta$ ); therefore, they were supposed to be impairing anti-tumor immune responses. Instead, solid evidence of an association of Treg density with favor- 
able prognosis [83-85] in human CRC suggest that they may in fact be beneficial for the restriction over protumorigenic inflammation [86].

Attention to B-cell infiltration in CRC has been raised by their frequent occurrence within tertiary lymphoid structures, organized environments of $\mathrm{T}$ and $\mathrm{B}$ cells commonly associated with favorable prognosis across cancers, including CRC [87-89]. Nonetheless, B cells infiltrating cancer tissues as scattered cells have been shown to possess protumor functions in other malignancies [90,91], suggesting that the local organization of B lymphocytes is an important feature, with impact on their function and prognostic significance.

Macrophages, the most abundant immune cells within the CRC microenvironment, have the capability to modulate every step leading to carcinogenesis and tumor progression [58,92-94]. In CRC, macrophages are orchestrators of an inflammatory milieu considered a driver of tumor initiation and progression [95]. Single-cell analyses identified six macrophage subsets, including two clusters of TAMs enriched in tumors and three clusters of recruited macrophages [61]. Despite this clear engagement in protumor functions, studies aimed at defining the prognostic role of macrophages in CRC have shown surprisingly association with favorable prognosis [96-98] and response to therapy [99].

\section{Links between Genetic Changes and the Immune-Contexture}

Clearly, a link exists between genetic damage and the host immune response, and again the lesson comes from MSI CRCs, which have long been known as deeply infiltrated by $\mathrm{T}$ cells [100]. Such association also led in the past to the inclusion of a dense immune infiltrate (as in Crohn's colitis) among the criteria advocated for MSI testing [101], long before universal screening for MMR defects were endorsed. High immunogenicity of MSI CRCs is sustained by their defective MMR, which results in large amounts of truncated peptides [102-104], acting as neo-antigens [105]. Thus, dense tumor infiltrating lymphocytes (TILs) are a sort of twin of most MSI CRCs [106], and sustain the associative link with better outcomes for this tumor type [49]. Yet, it is worth noting that high TIL amounts may not be the only reason for such a prognostic link. In MSI CRCs, the lack of CIN and of relevant damage in TSG is coupled with the peculiar genetic damage ensuing from the mutator that mutates other mutator pathways [103], which may not undergo the same type of selective pressure that pushes toward the enrichment of aggressive clones in MSS CRCs. MSI tumors are not the only ones significantly associated with dense TILs and better outcomes, as MSS CRCs with pathogenic somatic mutations in the POLE proofreading domain also share both high TILs and good outcomes [107,108]. Accordingly, "ultramutated" CRCs have a different clinical behavior, dictated by the type of genetic damage (whether it originates in the germline or in somatic cells), and sustained by the amount of adaptive immune reaction that they elicit.

It would be advisable to link the classifications pursued by DNA and mRNA data with those obtained by typing infiltrating immune cells, which include TILs but also innate cells, chiefly macrophages [109]. Such classification effort is meaningful, looking at patient outcome in various settings that should move from stage at diagnosis and include treatment [110]. An interesting paper published by Giannakis and colleagues joined the assessment of TILs with NGS analysis [111]. They found that even within MSS CRC, a high TIL amount correlates with high loads of neo-antigens. Other associations were with mutations in HLA genes and in members of the antigen-processing machinery.

Immune cells in the microenvironment of human CRC significantly correlate with postoperative tumor progression and response to therapy, fostering the development of new immune prognostic tools and increasing our ability to stratify patients into clinical subgroups. Most of the work done until now has focused on histopathological assessment, while high-resolution technologies are rapidly unearthing the complexity and diversity of immune cells in cancer tissues. In nonmetastatic settings, one could look for TNM together with biomarkers that could allow the prognostication of CRC cured from surgery alone and the prediction of responsiveness to adjuvant treatment of those requiring postsurgical therapy [110]. 


\section{Inflammation as an Accelerator of Carcinogenesis in Inflammatory Bowel Diseases}

The crucial role of immune hyperactivity and inflammation as cancer promoters is also exemplified by the increased risk of cancer in IBD patients, which is historically acknowledged, both for those affected by ulcerative colitis (UC) and Crohn's disease (CD). Therefore, the theme of cancer surveillance has become of growing importance in recent decades, in terms of early diagnosis, understanding of the mechanisms for carcinogenesis and awareness of the risk factors concerning this particular group of patients, including mucosal inflammation and long-term immunosuppression [58]. From an epidemiologic point of view, cancerous lesions usually develop in the adult age, but the adaptation of the treatment and the optimization of the management are of paramount importance for the long course of the disease, starting from the pediatric age.

With respect to the basic risk of developing specific cancers, pathogenesis and epidemiology, literature data are conflicted. Patients affected by UC included in a Finnish study demonstrated an increased risk of colon, rectal, biliary tract and thyroid cancers, with the risk of CRC being highest among the youngest patients. Patients with CD had a significantly increased risk for cancers of the small intestine, anus and biliary tract, and also for myeloma [112]. In contrast, data from Denmark indicated that only CD patients had an increased risk of developing malignancies overall, such as small bowel cancer, lung cancer or non-Hodgkin's lymphoma, while the general risk for developing cancer in UC patients was not increased [113]. Again, a large population-based study using Danish healthcare databases found that patients with IBD, particularly CD, were at an increased risk for gastrointestinal and extraintestinal malignancies [114]. One pediatric French population-based study estimated the risk of cancer in patients with childhood-onset CD (median age at diagnosis 14.6 years; median follow-up 11.4 years), and found a significant 2.5-fold increase compared with the background population [115]. A similar two-fold significant increased risk of cancer was also described in a Danish study that evidenced an overall risk of cancer in the population diagnosed at the age of 19 years or less of 2.17-fold, compared with the non-IBD population, and was the highest among the other age groups [116]. Overall, IBD are well-recognized risk factors for the development of colorectal and small bowel cancer; in particular, UC and colic CD are risk factors for CRC, with 2.2 times higher risk of developing CRC compared with the general population [117], which is specifically called colitis-associated colorectal cancer (CAC), while ileal CD has to be surveilled with regard to SBA. An updated meta-analysis of population-based cohort studies has quantified the incidence of CRC among patients with IBD to be $1 \%, 2 \%$ and $5 \%$ after 10,20 and $>20$ years of disease duration [118]. Another large meta-analysis assessing CRC risk in patients with IBD showed a risk of $2 \%$ at 10 years after UC diagnosis, $8 \%$ at 20 years and $18 \%$ at 30 years after colitis onset $[119,120]$. Taken together, CAC remains an important consequence of long-standing IBD, with an estimated incidence of approximately $5 \%$ after 20 years of disease duration [121]. Important clinical differences exist between CAC and sporadic CRC in the general population. The first is more common among young patients both in cases of UC and CD (average age of 50-60 years in IBD compared with 65-75 years for sporadic CRC in the general population) [122]; CAC is more likely to be found in the proximal colon $(51.5 \%)$ compared to sporadic CRC (36.4\%), especially in presence of primary sclerosing cholangitis (PSC) [123]. Furthermore, CACs are more commonly synchronous (15-20\% of CAC compared with $3-5 \%$ of sporadic CRC), have an increased frequency of mucinous or signet ring cell histology and bear generally different genetic alterations $[119,124,125]$. The evolution of the epidemiology of CACs over the years seems to show a reduction in the incidence rate. This result might be attributed to the improvement of therapies for patients with IBD and to the advent of surveillance colonoscopy programs with early colectomy $[122,126]$.

The principal risk factors for the development of CAC are: IBD diagnosis at young age ( $<15$ years) and longer duration of the disease; male sex; extensive colitis; persistence and severity of the inflammation; and coexistence of PSC [121,127]. An important marker of disease severity and persistence of inflammation may be the development of colonic 
strictures. Recent studies suggest that $2 \%$ to $3.5 \%$ of colonic strictures harbor dysplasia or CRC $[121,128,129]$. Unlike sporadic CRC, usually occurring as the end point of the adenoma-carcinoma sequence, CACs follow the sequence inflammation-dysplasia carcinoma [122].

Chronic inflammation and the degree of immunosuppression are the main driving factors for IBD-related carcinogenesis, which is a process of clonal evolution [119]. IBD-associated inflammation has the potential to mediate clonal evolution over time, by mechanisms of induced by oxidative stress, inflammatory chemokines and cytokine (IL- 6 , STAT3, TNF- $\alpha$, IL-10, IL-12 and IL-23) hyperproduction that affect numerous metabolic processes involved in cell repair, eventually creating a microenvironment that provides a selective advantage to those clones able to more rapidly repopulate the healing mucosa and to survive a cytotoxic inflammatory insult $[119,130]$.

A proper understanding of genetic mutations should allow a better stratification of IBD patients according to their risk for dysplasia and invasive carcinoma, in order to personalize their treatment and surveillance; for example, a recent study found that architectural distortion seems to be significantly correlated with p53 and p21 overexpression in epithelial cells. Several studies have identified the tissue expression of specific proteins such as p53 and p21 in patients with IBD, in order to identify the natural evolution of these biomarkers and their relationship with carcinogenesis [119,130]. CACs have increased mutation frequencies of various other intracellular and intercellular signaling molecules, such as IL-16, which is overexpressed in IBD in an inflammation-dependent manner, or RADIL, a gene encoding a modulator of Rho GTPase signaling in cell migration, which might provide a selective advantage in mucosal healing [119]. Emerging studies in the field of microbiome analysis are revealing the role of the gut microbiota and intestinal barrier function in tumorigenesis, and animal studies are beginning to shed some light on the complex and dynamic interplay between the altered immune system, the aberrant gut microbiome and cancer development in IBD. Specifically, it was hypothesized that dysbiosis, and changes in population of microbial species including Fusobacterium nucleatum $(F n)$, Bacteroides or Prevotella, might enhance CRC progression by simultaneously regulating multiple signaling cascades that could lead to upregulation of proinflammatory responses, oncogenes, modulation of host immune defense mechanisms and suppression of DNA repair systems [131,132].

\section{Micronutrients and Molecular Tuning of Colorectal Carcinogenesis}

\subsection{Vitamin D}

Among the multiple factors involved in cancer development and progression, vitamin D is assuming an increasingly important role due to its pleiotropic effects [133].

Vitamin D comprises a group of fat-soluble secosteroids responsible for increasing intestinal absorption of calcium, magnesium and phosphate, and many other biological effects. In humans, the most important compounds in this group are vitamin D3 (also known as cholecalciferol) and vitamin D2 (ergocalciferol). Vitamin D's influence on multiple biologic functions is expressed through the action of calcitriol, the product of a double hydroxylation of cholecalciferol, and the vitamin D3 receptor; therefore, aberrations in the physiological activity of Vitamin D may be a consequence of both its impaired serum concentration and defective receptor activity due to genetic mutations/variants [134].

The relationship between vitamin $\mathrm{D}$ and CRC has been explained both by epidemiologic studies evidencing low concentrations of the vitamin in subjects affected by cancer and by an alteration of its metabolic pathway in CRC tissues, although these findings do not have a clear clinical application yet [135]. Several studies have demonstrated its ability to interfere with cellular differentiation and proliferation both in normal and malignant tissues, with particular antiproliferative, proapoptotic, antimigration, anti-invasion, antiangiogenic and immunosuppressive activity in neoplastic cells $[133,136]$. The antiproliferative mechanism of vitamin $\mathrm{D}$ is due to the influence of calcitriol on cell cycle arrest in the resting 
phase G0/G1 by inducing the expression of the inhibitors of cyclin-dependent kinase, including p21, p27 and cystatin D, and stimulation of apoptosis [137-139].

Calcitriol was shown to upregulate miR-627, a ligand of the jumonji domain of histone demethylase, thus inhibiting the proliferation of CRC cells through epigenetic regulation in vitro and in vivo [139].

Vitamin D3 also promotes cell differentiation by increasing the expression of Ecadherin, cell adhesion proteins, alkaline phosphatase and maltase. Calcitriol is proved to inhibit $\beta$-catenin transcriptional activity in CRC cells, hence countering the aberrant activation of WNT- $\beta$-catenin pathway, which is the most commonly alternated signal pathway in sporadic CRC [140].

Moreover, the vitamin D receptor (VDR) inhibits cell proliferation and induces cell differentiation by binding to pi3k. Clinical trials showed that in KRAS-mutated/PI3Kmutated CRC tumor tissues, VDR was independently overexpressed [141]. Mocellin discussed epidemiologic data, suggesting a connection between vitamin D3 and cancer, and the results of clinical trials, which are conflicted [142]. Gandini et al. found that there was an inverse relationship between these levels and CRC [134,143].

The inhibition of angiogenesis was suggested in a paper by Pendas-Franco et al. that showed the ability of vitamin D to downregulate DKK-4, an antagonist of Wnt in CRC cells [144]; the same concept was also confirmed in papers by Meeker et al. and Shintani et al., who suggested vitamin D as anticancer agent due to its ability to inhibit growth of oral squamous cell carcinoma [145-147]. Antineoplastic roles of biologically active vitamin D3 includes the suppression of chronic inflammation, which indirectly inhibits cancer angiogenesis and invasion, and modulates the activity of factors related to cancer promotion (e.g., cyclooxygenase 2 (COX-2) and NF-kB). Another indirect evidence of anticancer properties of vitamin $\mathrm{D}$ is its role in the modulation of the immune response, and in particular inflammation $[145,148]$. Calcitriol may exert anti-inflammatory properties by inhibiting NF-kB signaling, the activation of which results in the production of proinflammatory cytokines $[149,150]$. Moreover, it may suppress p38 stress kinase signaling, therefore inhibiting the production of proinflammatory cytokines including IL-6, IL-8 and $\mathrm{TNF} \alpha$. Multiple studies have demonstrated the impact of vitamin D on lymphocytes CD4+ and CD8+, decreasing their proliferation, as well as on macrophages and dendritic cells, decreasing the secretion of proinflammatory cytokines after activation [145].

Although studies are limited, vitamin D has demonstrated to improve the cytotoxic activity of NK cells and the migration of dendritic cells into lymph nodes [151], overall modulating the immune response. The effects of active vitamin $\mathrm{D}$ are conveyed by its intracellular nuclear receptor VDR, the alterations and polymorphisms of which are responsible for an impaired activity of vitamin D. The VDR coding gene, located on the long arm of chromosome 12 (12q13-14), is associated with several SNPs, the most frequently studied being FokI, BsmI, Tru9I, ApaI and TaqI. Among them, the variation in FokI genotypes produces a smaller protein with increased activity. Several studies have demonstrated the association of the VDR polymorphisms with various diseases, including CRC [152,153], although results are still controversial and vary based on the considered population. A case-control study by Zhang et al. conducted in a Thai population failed to demonstrate significant associations between VDR SNPs and CRC, although a specific haplotype, AGGT, significantly predicted a lower risk of CRC [154]; moreover, the study found an interaction between dietary vitamin D intake and VDR ApaI genetic polymorphism in relation to the risk of CRC. A meta-analysis by Yu et al. suggested a moderate protective effect against CRC of the VDR BsmI polymorphism [155]. A study by Slattery et al. reported that the FokI (rs10735810), BsmI (rs11568820) and CDX2 (rs11568820) polymorphisms of VDR were associated with KRAS mutation in CRC [156]. Clinical consequences of such a broad spectrum of regulations of cell cycle and differentiation have been evaluated in several epidemiological studies that aimed to clarify whether vitamin $\mathrm{D}$ deficiency can be considered a risk factor for CRC, or conversely if vitamin D physiological serum concentration and eventual supplementation may represent protective factors against CRC. 
Over the last 20-30 years, several trials have been conducted, mostly finding a link between vitamin D deficiency and increased CRC risk and mortality [157-159], although other works could not confirm a statistical significance for this association. A meta-analysis by Lee et al. suggested an inverse association between circulating 25(OH)vitamin D levels and CRC (OR 0.77), with a stronger association for rectal cancer (OR 0.20) [160]. Similarly, a systematic review and meta-analysis by Yin et al. supported an inverse association between serum $25(\mathrm{OH})$ vitamin $\mathrm{D}$ and the risk of colon and rectal cancer, with odds ratios of 0.78 and 0.41 , respectively [161]. Besides the potential role of vitamin D as a protective factor for CRC, other studies focused on its effects on the outcome of affected patients. A metaanalysis by Li et al., although including heterogeneous studies, confirmed that patients with the highest quartile of circulating 25(OH)vitamin D had a better overall survival compared to those in the lowest quartile [162]. With the aim to apply vitamin $\mathrm{D}$ as a prognostic marker for CRC patients, a recent study by Yuan et al. also investigated the relationships between plasma vitamin D binding protein (VDBP), bioavailable or free $25(\mathrm{OH})$ vitamin $\mathrm{D}$ and CRC survival, concluding that prediagnostic circulating concentrations of VDBP were positively associated with survival, while neither bioavailable nor free $25(\mathrm{OH})$ vitamin D levels were associated with overall or CRC-specific mortality [163]. Starting from these premises, other studies focused on the potential usefulness of vitamin D supplementation to improve CRC patient management. A systematic review with a meta-analysis of randomized controlled trials by Vaughan-Shaw et al. examined the effect of vitamin D supplementation on survival outcomes in patients with CRC, concluding that supplementation imparts a $30 \%$ reduction in adverse survival outcomes overall, with a $24 \%$ reduction in CRC-specific death and a 33\% reduction in disease progression or death [164]. Overall, vitamin D seems to have a promising role as a prognostic factor for CRC patients' outcome and an easy element to improve in case of deficiency, being widely available and cheap to apply in large populations at all ages.

\subsection{Calcium}

Strictly related to vitamin D, calcium has also been explored as a molecule impacting on CRC risk. Being a ubiquitous second messenger, and signaling for a variety of cellular processes such as control of the cell cycle, apoptosis and migration, calcium activates a variety of ion-specific channels, cotransporters and pumps. The expression of several genes coding for calcium channels has demonstrated to be upregulated in CRC cells, including TRPC1 and TRPM2 [165,166], the activity of which has been related to the promotion of metastases; while TPRM6, the expression of which has been related to better patient survival, has been found to be downregulated in CRC cells [167]. Moreover, stromal interaction proteins 1 and 2 were revealed to be up- and downregulated in CRC, respectively, causing increased CRC cell motility and apoptosis resistance $[168,169]$. Besides regulating cell signaling, clinical applications of calcium supplementation with diet and cancer risk or progression have also been explored. Although cancer proliferation has been associated with an upregulation of calcium [170], Garland et al. found that a calcium-rich diet reduced the risk of CRC [171]. A systematic review of randomized controlled trials found that calcium supplementation with doses from 1200 to $2000 \mathrm{mg} /$ day and treatment duration from 36 to 60 months reduced the risk of recurrent colorectal adenomas ( $R R=0.89$, 95\% CI: 0.82-0.96, 5 studies, 2984 participants) [172]. It was proposed that calcium binds bile acids in the bowel lumen, inhibiting their proliferative and carcinogenic effects [173]. In support of this hypothesis, studies in animals have indicated a protective effect of dietary calcium on bile-induced mucosal damage and experimental bowel carcinogenesis [174].

Although the biochemical and the clinical behavior of calcium with regard to CRC seem contrasting, calcium signaling promotes or inhibits cancer based on the ability of the tissue environment to maintain balance of its intra- and extracellular concentrations: the increase of intracellular calcium promotes cancer progression, but once the level has reached overload, cancer cell death is favored, deteriorating cancerous tissue. Although 
the clinical application of such behavior is not yet available, calcium channels may present as possible drug targets to reduce tumor burden [175].

\section{Attempting Pharmacological Interference with CRC Development: Chemoprevention}

In the last decades, the growing knowledge about the physiopathology of CRC and its molecular players has allowed researchers to shed light on the potential application of drugs as preventive tools. Chemoprevention refers to the long-term use of a variety of oral medications that can delay, prevent or even reverse the development of colonic adenomas, and interfere with the multistep progression from adenoma to carcinoma.

Focusing on IBD patients, the use of maintenance therapies, and notably the better control of inflammation by improved medical therapy and higher rates of mucosal healing, could be important strategies for reducing CRC risk in UC patients [176]. Literature data about the preventive effect of specific drugs on the development of CAC are scarce; moreover, the available studies are focused on the use of the first molecules used for the treatment of IBD, while long-term trials about the effect of biologic therapies are awaited. 5-ASA is a first-line agent for IBD therapy. This molecule is able to reduce oxidative stress, inhibit cell proliferation and promote apoptosis. Most reports indicated that 5-ASA reduces the risk of CRC in UC, although literature data are controversial $[177,178]$. This protective effect has also been studied in $\mathrm{CD}$; a study by Cahil et al. concluded that the use of salicylates is protective against SBA [179]. Overall, the protective effect of immunomodulators is primarily due to their role in the control of inflammation [180]. Ursodeoxycholic acid (UDCA) may be a practical chemoprevention against colonic exposure to bile acid in patients with PSC. UDCA reduces the colonic concentration of the secondary bile acid as a carcinogen [126]. Given the known importance of TNF and interleukins within the pathogenesis of CAC, more targeted inhibition of these pathways may offer an opportunity to prevent $C A C$, particularly among high-risk individuals who have developed early dysplastic lesions, where these cytokines serve to stabilize the cancer microenvironment. Animal models have suggested that TNF antagonists may prevent the development or progression of dysplasia and cancer, and some population-based data within IBD have demonstrated a lower frequency of CRC among those treated with infliximab.

Although the role of anti-inflammatory agents as chemopreventive drugs is crucial in CAC, these medications have been considered for sporadic and hereditary CRC for decades [181].

Aspirin has been the first extensively investigated drug in the chemoprevention of colorectal adenomas and cancer, thanks to its ability to inhibit COX-1 and COX-2 enzymes, both of which are important mediators of prostaglandin production. In 1988, a population-based case-control study by Kune et al. demonstrated that regular aspirin users showed a relative risk of 0.53 of developing CRC, compared with nonconsumers [182]. Since then, several large studies have been developed, agreeing on the protective role of aspirin against CRC $[183,184]$. Unfortunately, aspirin has several well-known side effects, including gastrointestinal hemorrhage, renal toxicity, and risk of developing Reye's syndrome [185] or Stevens-Johnson syndrome. Being that most side effects of aspirin and NSAIDs in general are related to their inhibition of COX-1, selective drugs to inhibit COX-2 have been developed and applied not only in the treatment of inflammation, but also in chemoprevention of $\mathrm{CRC}$, also justified by the demonstration of an overexpression of COX2 in adenomatous lesions [186]. In particular, hereditary syndromes at risk of developing CRC have been addressed, including FAP and Lynch syndrome [187]. In 2000, a doubleblind, placebo-controlled study by Steinbach et al. conducted on 77 patients affected by FAP demonstrated a significant reduction of the number of polyps after 6 months of treatment with oral celecoxib [187]. A recent double-blind, placebo-controlled trial by Burn et al. reporting a 10-year follow-up of 861 patients affected by Lynch syndrome demonstrated a significantly reduced risk of developing CRC for aspirin consumers compared to the placebo group (HR 0.65), with a similar adverse-events rate between groups [188]. Overall, evidence is in favor of NSAIDs' long-term use in the case of hereditary syndromes at 
risk of developing CRC, although this type of chemoprevention is not yet uniform nor systematically used worldwide, probably because the risk/benefit ratio and the optimal dosing have not yet been standardized.

\section{Microbial Hosts: Fusobacterium Nucleatum}

Considering the environmental factors potentially participating in CRC onset and progression, in the last decades, growing attention has been paid to the role of the intestinal microbiota alterations. Among bacteria, $F n$ may contribute to CRC development through multiple mechanisms, including the interaction with the host immune system, the production of cancer-associated metabolites and the release of genotoxic virulence factors $[189,190]$. The protumorigenic role of $F n$ and its association with CRC are supported by several studies and experimental models [191,192].

First, $F n$ has demonstrated to be enriched in CRC lesions compared to matched normal colonic mucosa; moreover, $F n$ sequences were found in lymph node and distant metastases [193,194]. The cancerogenic mechanisms of $F n$ start from the adhesion and invasion of the enterocytes by the bacterium, thanks to adhesion molecules (FadA and Fap2) able to recognize epithelial cells. After adhesion, $F n$ activates the $\beta$-catenin and NF-kB signaling pathways [195] as FadA-cadherin-E binding accelerates carcinogenesis in the presence of genetic alterations by beta-catenin activation; moreover, Fap2-TIGIT binding promotes tumor survival by smoldering antitumor immunity [196]. However, Fn cannot be yet considered a carcinogen per se, but rather a promoter of cancer progression in cells already altered by an initiating factor [192,197]. Studies also suggested than Fn could trigger EMT in the neoplastic colonic cells, promoting proliferation and invasion by enhancing the expression of EMT-related genes (E-cadherin and N-cadherin) $[198,199]$.

Besides its mechanisms of action, Fn seems to play a double-faceted role in CRC progression and clinical behavior. Although $F n$ enrichment in stool or epithelial samples is associated with mucosal degeneration, presence of metastases $[193,194,200]$ and chemoresistance [201] and increased risk of disease-specific mortality [202,203], Fn-positive CRCs are more frequently characterized by microsatellite instability [202,204,205], a group of tumors classified as usually having better prognosis than their counterpart microsatellite stable CRC, due to their higher immune infiltrate (TILs) and low metastatic potential $[25,110,206]$. Therefore, $F n$ could be intended as an accelerator of the carcinogenesis process and a modifier of cancer clinical behavior in a specific subset of tumors, namely MSI cancers. However, most recent data also implicate $F n$ in the responsiveness of locally advanced rectal cancers to neoadjuvant therapy. In such a setting, the persistence of $F n$ after therapy was associated with a worse outcome in two independent studies from Europe and Asia $[207,208]$. Accordingly, the role of $F n$ in CRC might be wider and more relevant than previously thought. Noticeably, large differences in study methodologies may account for discrepancies in findings so far, and the field requires appropriate validations in different clinical-pathological settings.

\section{The Frame for Biomarker Actionability: TNM Staging System Turning in the 21st Century}

The stage of cancer by the TNM system describes its advancement based on its local extent at the site of origin (T), coupled to the presence or absence of the involvement of the regional lymph nodes $(\mathrm{N})$, and eventually of metastases at distant sites (M) [209]. The TNM continues to represent the cornerstone prognostic system for solid malignancies, although the American Joint Committee on Cancer (AJCC) has increasingly acknowledged the necessity to move toward individualized, more precise outcome estimates, mainly through the application of accurate risk models and calculators [210,211] incorporating nonanatomic prognostic features. Regarding CRC, in the latest AJCC 8th edition [209], published in 2016, particular emphasis has been given to MMR deficiency sustained by germline and somatic mutations or epigenetic changes, as well to RAS pathway mutations (i.e., KRAS, BRAF and NRAS). Still, a key drawback of risk calculators is the incapability to convey with heterogeneity within each stage groups. 
The spread of cancer cells from the primary tumor to tumor-draining lymph nodes defines stage III CRC disease, and is the most relevant prognostic factor triggering the administration of adjuvant chemotherapy. The relationship between lymph nodes and distant metastases has been acknowledged since the 19th century, and together with the finding that lymph node disease frequently precedes systemic disease, has since then prompted the conception that surgical resection of positive lymph nodes may decrease the rate of recurrence. However, results from clinical trials have suggested that lymph node resection does not always increase patient survival [212], rousing the different notion that lymph node metastases do not necessarily imply distant metastatic spread [213]. This alternative view could be in line with the wide variability in survival rates within stage III CRC, ranging between $70 \%$ for T1N1a and $10-15 \%$ for T4bN2b tumors $[214,215]$, despite adjuvant chemotherapy. A pooled analysis of more than 12,000 stage III CRC patients enrolled in the IDEA trial confirmed the large variability of five-year disease-free survival (DFS) within 16 substages based on $\mathrm{T}$ and $\mathrm{N}$ categories, ranging from $89 \%$ for T1N1a to $31 \%$ for T4N2b CRC [216]. Interestingly, the analysis also evaluated the contribution of each therapeutic option across the different substages. The authors used a metaregression model to estimate the five-year DFS within each $\mathrm{T}$ and $\mathrm{N}$ subgroup. While the projected five-year DFS for T1N1 cancer patients treated with surgery alone was $79.6 \%$, patients with $\mathrm{T} 4 \mathrm{~N} 2 \mathrm{~b}$ disease showed a $13.9 \%$ five-year DFS with surgery alone, with an additional $11.2 \%$ absolute gain with adjuvant fluoropyrimidines alone, an additional $6.4 \%$ with oxaliplatin for three months and $2.5 \%$ with oxaliplatin for six months (Figure 2). These data underline the existence of distinct prognostic categories within stage III CRC contemporarily, implying a reappraisal of the bases of current treatment strategies. Likewise, a better interpretation of the link between lymph node involvement and the development of distant metastases is pivotal, considering the changes related to empirical treatment strategies.

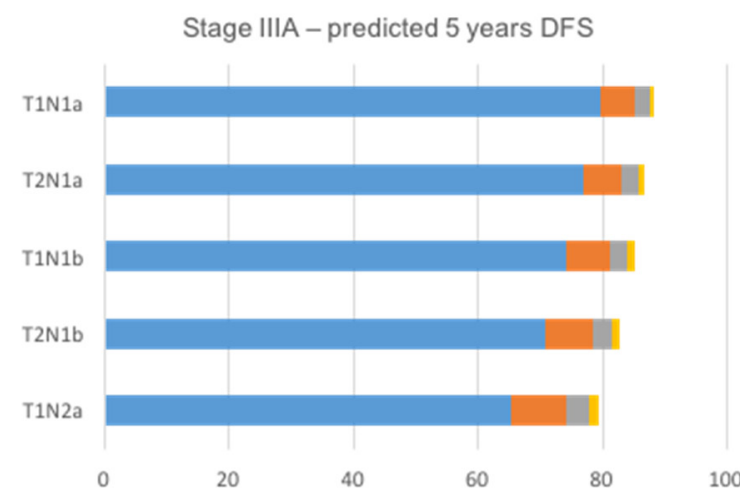

Stage IIIC - predicted 5 years DFS

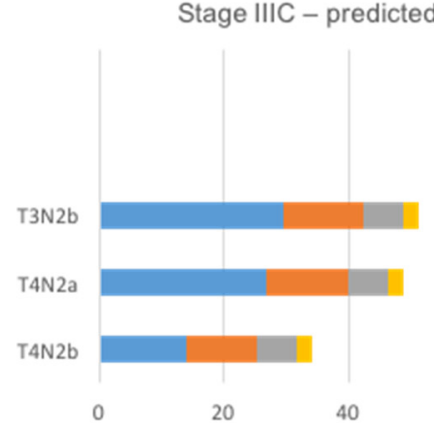

Stage IIIB - predicted 5 years DFS

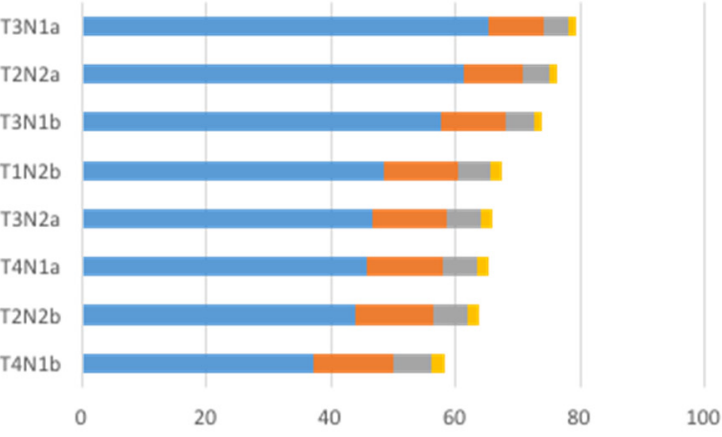

Surgery alone

Fluoropyrimidines

Oxaliplatin 3 months

Oxaliplatin 6 months

Figure 2. Prognostic subgroups within stage III colon cancers by therapeutic options: surgery alone; fluoropyrimidine alone; oxaliplatin-based doublet for 3 months; oxaliplatin-based doublet for 6 months.

The conceptual framework of the TNM staging system is seeded in the concept of the sequential progression of metastatic cascade, in which cancer cells from the primary 
tumor $(\mathrm{T})$ seed local lymph node dissemination $(\mathrm{N})$ that may eventually lead to metastases at distant sites (M) [217]. Metastatic spreading has been depicted in several genome sequencing studies that have revealed a clonal evolution of cells from primary tumor to metastatic sites $[218,219]$. Conversely, another view would posit that cancer cells can spread as early as from preneoplastic lesions $[220,221]$ and from early-stage primary tumors, the vasculature abnormalities of which favor the escape of cancer cells into the circulation [222]. At any event, it remains unclear whether a distinct metastatic subclone develops in the primary tumor, afterwards disseminating to lymph nodes and distant sites [223-225], or whether multiple subclones in the primary tumor separately scatter lymphatic and distant metastases [219,226,227]. To evaluate the evolutionary origin of lymphatic and distant metastases, Naxerova and colleagues [228] studied 213 CRC specimens from 17 patients, showing that in up to $70 \%$ of the cases, lymphatic and distant metastases developed from independent subclones in the primary tumor. Thus, in the majority of patients, lymphatic and distant metastases might have an independent origin. Still, around $30 \%$ of cases shared a common subclonal origin.

\section{Molecular Heterogeneity and Metastatic Seeding}

Besides the timing of cancer cell spreading, it remains largely unclear how cancer cells develop the capability to colonize distant tissues. This ability may arise during primary tumor growth as a consequence of intrinsic properties of the tumor cells and of (faulty) host response, or as the effect of the selective pressure on previously spread cancer cells to adapt to distant tissue microenvironments [229]. Interaction among tumor cells themselves, as well as between host and tumor cells, can cause alterations in their behavior and plasticity. For example, hypoxia may exert a negative selection against $R A S$-mutant clones through a mechanism identified as secretory senescence [230]. In addition, KRAS-mutant senescent cells can then induce the development of RAS wild-type subpopulations by a paracrine mechanism, leading to their progressive outgrowth [231,232].

A better understanding of the biology of the development of metastases and of the properties of the cells selected along this process is critical for precision medicine and treatment selection for patients with systemic disease. Still, identification of the hallmarks of metastatic potential has been complex due to heterogeneity among tumor cells [233]. Throughout primary tumor evolution, abnormal levels of genetic instability lead to the development of cells with newly acquired features [233,234]. Several studies have assessed the genetic and phenotypic diversity of the tumor cells that encompass primary tumors [235]; nevertheless, the level of genetic and epigenetic heterogeneity and phenotypic plasticity below metastatic growth remains undefined. Single-cell and sequencing data indicate that some metastases develop from separate lineages [228,236-240], and metastases themselves can generate other metastases $[236,241]$. Hence, heterogeneity is part of an evolutionary and temporal process [242], yet it has a critical role in drug resistance and disease progression by preventing efficacy of single targeted therapy (Figure 3). As concerns CRC, Ciardiello and colleagues [243] have depicted specific molecular alterations differing among cancers (i.e., intertumor heterogeneity), as well as the presence of cancer cells with distinct molecular alterations within the same tumor sample (i.e., intratumor heterogeneity). 


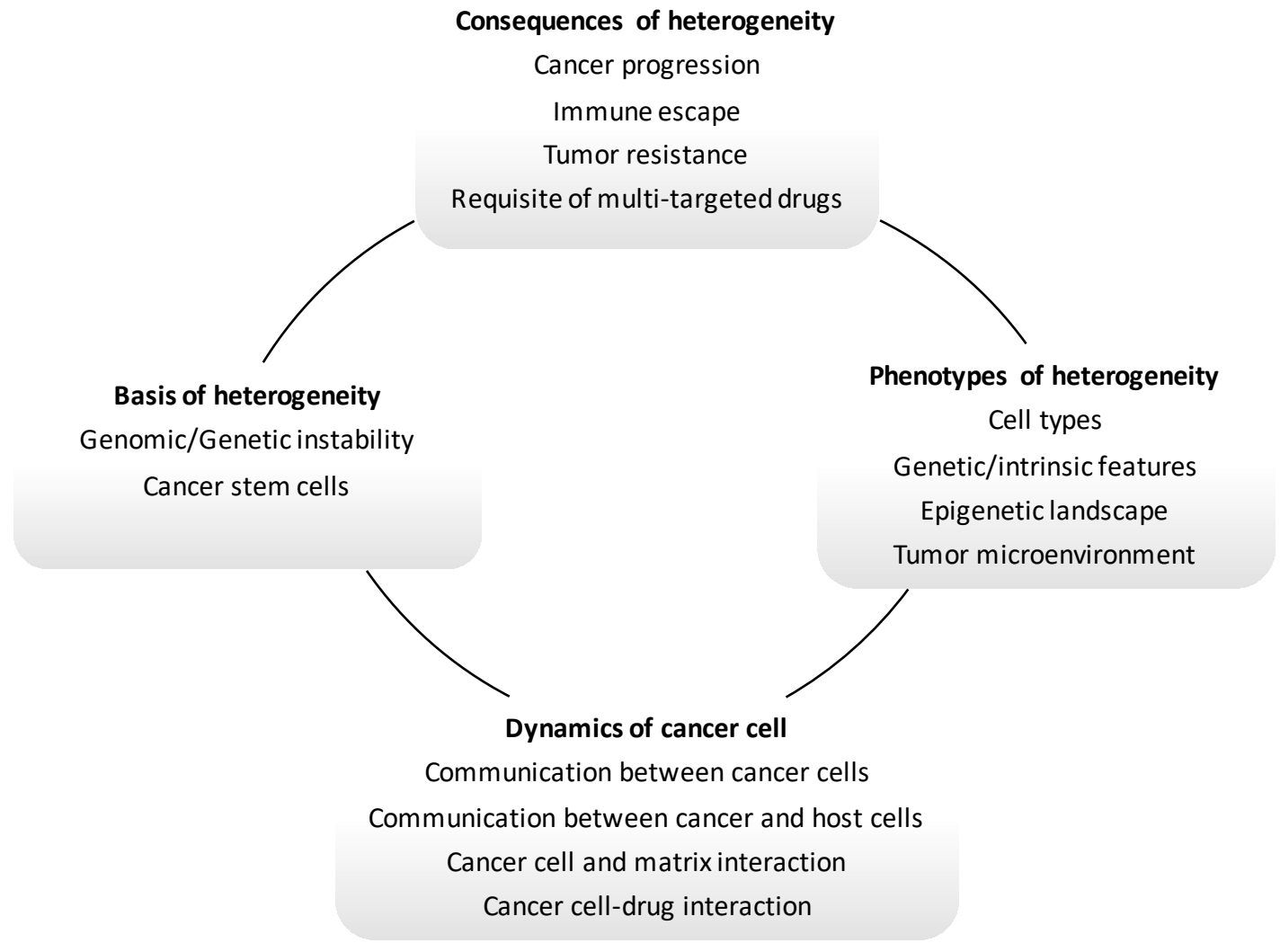

Figure 3. Principles of temporal and spatial heterogeneity of cancer.

\section{Molecular Heterogeneity and the Emergence of Resistance to Target Treatment in Metastatic CRC}

Mutations along the RAS pathway are responsible for both primary and acquired resistance to anti-epidermal growth factor receptor (EGFR) therapies [230,244-251]. In various cases, $R A S$ mutations arise early during CRC carcinogenesis, as a clonal (truncal) mutation maintained in primary and metastatic lesions [9,252], and $R A S$-mutant tumors are unresponsive to anti-EGFR therapies. Still, notwithstanding stringent selection based on screening for somatic RAS mutations, about $65-70 \%$ of patients progress within three to 12 months after initial anti-EGFR therapies. Analysis of post-treatment samples has revealed acquired resistance as a major limitation of therapies targeting oncoproteins such as EGFR and BRAF [253]. Seminal studies on plasma-cell-free DNA have shown that under drug selective pressure, undetectable $R A S$-mutant subpopulations at baseline undertake a clonal expansion, preceding acquired therapy resistance [254-256]. The clinical managing of patients who acquire RAS mutations subsequent to EGFR inhibition is doubtful. At progression, the majority of patients receive further lines of therapies based on chemotherapy alone or combined with antiangiogenic drugs, and eventually a monotherapy with the multikinase inhibitor regorafenib. Siravegna and colleagues [256] showed that KRASmutant alleles, which develop at the time of disease progression, decline when anti-EGFR treatment is interrupted, persisting under the limit of detection across succeeding lines of treatment. The decline of KRAS-mutant alleles detected in blood from patients after interruption of the anti-EGFR blockade [257] suggests not only a dynamic evolution of cancer cells, but also that a rechallenge therapy may be a clinically valuable choice in these patients, as CRC secondary lesions are likely to respond to anti-EGFR rechallenge [258].

Other changes can occur under the pressure of treatments. Drug-tolerant cancer cells that survive EGFR/BRAF inhibitor treatment show a decreased expression of mismatch and homologous recombination (HR) proteins, and increase their mutagenic rate [259]. All these alterations may trigger the RAS-MEK-ERK pathway [246,260-262]. Therefore, though 
resistance to anti-EGFR inhibitors can be polyclonal, it mostly converges on the downstream signaling pathways of EGFR [253]. In addition, the efficacy of monoclonal antibodies targeting a single pathway has been mainly limited by the occurrence of compensatory feedback loops in other pathways, such as increased secretion of vascular endothelial factor (VEGF) during anti-EGFR treatment [263].

The molecular heterogeneity detectable following anti-EGFR therapy emphasizes how a single therapeutic approach is unlikely to overwhelm extensive mechanisms of resistance, as most of these alterations involve multiple pathways in a single patient. Hence, the picture of tumor heterogeneity at the time of secondary resistance, as depicted for EGFR inhibitors, indicate that multitargeted drug combinations before relapse could better target the bulk tumor cells and reduce the expected acquired resistance mechanisms, thus providing a substantial improvement in survival compared with administration at progression [264,265].

\section{Restraining the Progression of Metastatic CRC: The Frontier}

The latest scientific enhancements of molecular diagnostics; i.e., blood-based tumor genotyping, have permitted the assessment of clonal evolution in patients with cancer, and introduced the new concept of time, to guide adaptive therapy strategies.

Regorafenib is an oral multikinase inhibitor approved by both the Food and Drug Administration and the European Medicines Agency for CRC patients who have not responded to available therapies [266]. It inhibits three oncogenic pathways, specifically: (a) cell growth by inhibition of KIT, RET, RAF-1 and BRAF; (b) tumor angiogenesis by targeting vascular endothelial growth factor receptors (VEGFR) 1, 2 and 3, and the tyrosine kinase with immunoglobulin and EGF homology domain 2 (TIE2); and (c) the tumor microenvironment by hampering fibroblast growth factor receptor (FGFR) and platelet-derived growth factor receptor-b (PDGR-b) [267-269]. The combined treatment with cetuximab and regorafenib prompts synergistic antiproliferative and proapoptotic effects by blocking MAPK and AKT pathways both in vitro and in vivo [270], and is a potential approach worth exploring in an attempt to overwhelm primary or secondary resistance to EGFR inhibitors in patients with advanced CRC. The results of the REVERCE randomized phase II trial suggest that the sequence of second-line regorafenib followed by cetuximab/irinotecan in CRC after failure of fluoropyrimidine, oxaliplatin and irinotecan is associated with a longer survival compared with the standard sequence of cetuximab/irinotecan followed by regorafenib [271]. Biomarker analyses have revealed earlier occurrence of changes in RAS, BRAF, EGFR, HER2 and MET, commonly associated with resistance to anti-EGFR therapy $[246,255,272,273]$ after cetuximab compared with regorafenib, thus explaining the poorer outcomes with cetuximab in the first treatment arm compared with regorafenib given first. The randomized REVERCE II trial (NCT04117945) comparing regorafenib followed by anti-EGFR monoclonal antibody therapy versus the reverse sequencing for metastatic CRC patients formerly treated with fluoropyrimidine, oxaliplatin and irinotecan is currently ongoing, and will probably provide further data concerning the optimal sequence of treatments.

The expected utility of liquid biopsy in this setting is to identify the circulating clonal background in cancer patients through the analysis of circulating tumor DNA, providing innovative and clinically meaningful understandings of tumor heterogeneity sustaining drug resistance [274]. Acquired resistance to EGFR-targeted monoclonal antibodies has been extensively associated with the emergence of RAS pathway mutations detectable in the blood of patients before the appearance of clinically manifest disease progression $[254,257,275]$. Contrariwise, the selective pressure exerted by antiangiogenic drugs in CRC patients with $R A S$-mutant disease has been less frequently examined. Liquid biopsy under antiangiogenic treatment has revealed the relative prevalence of $R A S$ wild-type clones, which can be translated in a clinically significant advantage for patients. Targeting this gap with EGFR inhibitors potentially could provide an available second-line choice in RAS-mutant CRC. The KAIROS trial (Keeping the Advantage of the Impermanent RAS-Wild Type Window 
Offering Second-Line EGFR Inhibitors, EudraCT Number 2019-001328-36) may help to establish whether the response to EGFR blockade, in patients with $R A S$-mutant primary tumors could switch to RAS wild-type clones during first-line antiangiogenic therapy.

Over the decades, the vision on CRC has tremendously changed. The application of genetics, NGS, advances in immunology and the understanding of the value of TME, micronutrients and the microbiome are leading to a deeper understanding of the multifaceted behavior and subtypes of CRC, providing the bases for precision medicine, with the aim to improve the patient's outcome.

Author Contributions: Each author contributed in writing of the review. All authors have read and agreed to the published version of the manuscript.

Funding: Associazione Italiana Ricerca sul Cancro: AIRC: IG 2014 Id.16092.

Conflicts of Interest: The authors declare no conflict of interest.

\section{References}

1. Leppert, M.; Dobbs, M.; Scambler, P.; O'Connell, P.; Nakamura, Y.; Stauffer, D.; Woodward, S.; Burt, R.; Hughes, J.; Gardner, E.; et al. The gene for familial polyposis coli maps to the long arm of chromosome 5. Science 1987, 238, 1411-1413. [CrossRef] [PubMed]

2. Solomon, E.; Voss, R.; Hall, V.; Bodmer, W.F.; Jass, J.R.; Jeffreys, A.J.; Lucibello, F.C.; Patel, I.; Rider, S.H. Chromosome 5 allele loss in human colorectal carcinomas. Nature 1987, 328, 616-619. [CrossRef] [PubMed]

3. Bodmer, W.F.; Bailey, C.J.; Bodmer, J.; Bussey, H.J.; Ellis, A.; Gorman, P.; Lucibello, F.C.; Murday, V.A.; Rider, S.H.; Scambler, P.; et al. Localization of the gene for familial adenomatous polyposis on chromosome 5. Nature 1987, 328, 614-616. [CrossRef]

4. Knudson, A.G., Jr. Mutation and cancer: Statistical study of retinoblastoma. Proc. Natl. Acad. Sci. USA 1971, 68, 820-823. [CrossRef]

5. Fearnhead, N.S.; Britton, M.P.; Bodmer, W.F. The ABC of APC. Hum. Mol. Genet. 2001, 10, 721-733. [CrossRef] [PubMed]

6. Bos, J.L.; Fearon, E.R.; Hamilton, S.R.; Verlaan-de Vries, M.; van Boom, J.H.; van der Eb, A.J.; Vogelstein, B. Prevalence of ras gene mutations in human colorectal cancers. Nature 1987, 327, 293-297. [CrossRef]

7. Fearon, E.R.; Hamilton, S.R.; Vogelstein, B. Clonal analysis of human colorectal tumors. Science 1987, 238, 193-197. [CrossRef] [PubMed]

8. $\quad$ Baker, S.J.; Fearon, E.R.; Nigro, J.M.; Hamilton, S.R.; Preisinger, A.C.; Jessup, J.M.; vanTuinen, P.; Ledbetter, D.H.; Barker, D.F.; Nakamura, Y.; et al. Chromosome 17 deletions and p53 gene mutations in colorectal carcinomas. Science 1989, 244, $217-221$. [CrossRef] [PubMed]

9. Vogelstein, B.; Fearon, E.R.; Hamilton, S.R.; Kern, S.E.; Preisinger, A.C.; Leppert, M.; Nakamura, Y.; White, R.; Smits, A.M.; Bos, J.L. Genetic alterations during colorectal-tumor development. N. Engl. J. Med. 1988, 319, 525-532. [CrossRef]

10. Fearon, E.R.; Vogelstein, B. A genetic model for colorectal tumorigenesis. Cell 1990, 61, 759-767. [CrossRef]

11. Boland, C.R. Evolution of the nomenclature for the hereditary colorectal cancer syndromes. Fam. Cancer 2005, 4, 211-218. [CrossRef]

12. Boland, C.R.; Lynch, H.T. The history of Lynch syndrome. Fam. Cancer 2013, 12, 145-157. [CrossRef]

13. Ionov, Y.; Peinado, M.A.; Malkhosyan, S.; Shibata, D.; Perucho, M. Ubiquitous somatic mutations in simple repeated sequences reveal a new mechanism for colonic carcinogenesis. Nature 1993, 363, 558-561. [CrossRef] [PubMed]

14. Aaltonen, L.A.; Peltomaki, P.; Leach, F.S.; Sistonen, P.; Pylkkanen, L.; Mecklin, J.P.; Jarvinen, H.; Powell, S.M.; Jen, J.; Hamilton, S.R.; et al. Clues to the pathogenesis of familial colorectal cancer. Science 1993, 260, 812-816. [CrossRef] [PubMed]

15. Thibodeau, S.N.; Bren, G.; Schaid, D. Microsatellite instability in cancer of the proximal colon. Science 1993, 260, 816-819. [CrossRef] [PubMed]

16. Peltomaki, P. Update on Lynch syndrome genomics. Fam. Cancer 2016, 15, 385-393. [CrossRef] [PubMed]

17. Kane, M.F.; Loda, M.; Gaida, G.M.; Lipman, J.; Mishra, R.; Goldman, H.; Jessup, J.M.; Kolodner, R. Methylation of the hMLH1 promoter correlates with lack of expression of hMLH1 in sporadic colon tumors and mismatch repair-defective human tumor cell lines. Cancer Res. 1997, 57, 808-811.

18. Cunningham, J.M.; Christensen, E.R.; Tester, D.J.; Kim, C.Y.; Roche, P.C.; Burgart, L.J.; Thibodeau, S.N. Hypermethylation of the hMLH1 promoter in colon cancer with microsatellite instability. Cancer Res. 1998, 58, 3455-3460. [PubMed]

19. Herman, J.G.; Umar, A.; Polyak, K.; Graff, J.R.; Ahuja, N.; Issa, J.P.; Markowitz, S.; Willson, J.K.; Hamilton, S.R.; Kinzler, K.W.; et al. Incidence and functional consequences of hMLH1 promoter hypermethylation in colorectal carcinoma. Proc. Natl. Acad. Sci. USA 1998, 95, 6870-6875. [CrossRef]

20. Aaltonen, L.A.; Salovaara, R.; Kristo, P.; Canzian, F.; Hemminki, A.; Peltomaki, P.; Chadwick, R.B.; Kaariainen, H.; Eskelinen, M.; Jarvinen, H.; et al. Incidence of hereditary nonpolyposis colorectal cancer and the feasibility of molecular screening for the disease. N. Engl. J. Med. 1998, 338, 1481-1487. [CrossRef] 
21. Giardiello, F.M.; Allen, J.I.; Axilbund, J.E.; Boland, C.R.; Burke, C.A.; Burt, R.W.; Church, J.M.; Dominitz, J.A.; Johnson, D.A.; Kaltenbach, T.; et al. Guidelines on genetic evaluation and management of Lynch syndrome: A consensus statement by the US Multi-Society Task Force on colorectal cancer. Gastroenterology 2014, 147, 502-526. [CrossRef] [PubMed]

22. Kinzler, K.W.; Vogelstein, B. Lessons from hereditary colorectal cancer. Cell 1996, 87, 159-170. [CrossRef]

23. Sankila, R.; Aaltonen, L.A.; Jarvinen, H.J.; Mecklin, J.P. Better survival rates in patients with MLH1-associated hereditary colorectal cancer. Gastroenterology 1996, 110, 682-687. [CrossRef] [PubMed]

24. Gryfe, R.; Kim, H.; Hsieh, E.T.; Aronson, M.D.; Holowaty, E.J.; Bull, S.B.; Redston, M.; Gallinger, S. Tumor microsatellite instability and clinical outcome in young patients with colorectal cancer. N. Engl. J. Med. 2000, 342, 69-77. [CrossRef]

25. Malesci, A.; Laghi, L.; Bianchi, P.; Delconte, G.; Randolph, A.; Torri, V.; Carnaghi, C.; Doci, R.; Rosati, R.; Montorsi, M.; et al. Reduced likelihood of metastases in patients with microsatellite-unstable colorectal cancer. Clin. Cancer Res. 2007, 13, 3831-3839. [CrossRef]

26. Watanabe, T.; Wu, T.T.; Catalano, P.J.; Ueki, T.; Satriano, R.; Haller, D.G.; Benson, A.B., 3rd; Hamilton, S.R. Molecular predictors of survival after adjuvant chemotherapy for colon cancer. N. Engl. J. Med. 2001, 344, 1196-1206. [CrossRef]

27. Laghi, L.; Malesci, A. Microsatellite instability and therapeutic consequences in colorectal cancer. Dig. Dis. 2012, 30, 304-309. [CrossRef]

28. Sargent, D.J.; Marsoni, S.; Monges, G.; Thibodeau, S.N.; Labianca, R.; Hamilton, S.R.; French, A.J.; Kabat, B.; Foster, N.R.; Torri, V.; et al. Defective mismatch repair as a predictive marker for lack of efficacy of fluorouracil-based adjuvant therapy in colon cancer. J. Clin. Oncol. 2010, 28, 3219-3226. [CrossRef]

29. Le, D.T.; Uram, J.N.; Wang, H.; Bartlett, B.R.; Kemberling, H.; Eyring, A.D.; Skora, A.D.; Luber, B.S.; Azad, N.S.; Laheru, D.; et al. PD-1 Blockade in Tumors with Mismatch-Repair Deficiency. N. Engl. J. Med. 2015, 372, 2509-2520. [CrossRef]

30. Kuismanen, S.A.; Holmberg, M.T.; Salovaara, R.; Schweizer, P.; Aaltonen, L.A.; de La Chapelle, A.; Nystrom-Lahti, M.; Peltomaki, P. Epigenetic phenotypes distinguish microsatellite-stable and -unstable colorectal cancers. Proc. Natl. Acad. Sci. USA 1999, 96, 12661-12666. [CrossRef]

31. Ahuja, N.; Mohan, A.L.; Li, Q.; Stolker, J.M.; Herman, J.G.; Hamilton, S.R.; Baylin, S.B.; Issa, J.P. Association between CpG island methylation and microsatellite instability in colorectal cancer. Cancer Res. 1997, 57, 3370-3374.

32. Toyota, M.; Ahuja, N.; Ohe-Toyota, M.; Herman, J.G.; Baylin, S.B.; Issa, J.P. CpG island methylator phenotype in colorectal cancer. Proc. Natl. Acad. Sci. USA 1999, 96, 8681-8686. [CrossRef]

33. Kambara, T.; Simms, L.A.; Whitehall, V.L.; Spring, K.J.; Wynter, C.V.; Walsh, M.D.; Barker, M.A.; Arnold, S.; McGivern, A.; Matsubara, N.; et al. BRAF mutation is associated with DNA methylation in serrated polyps and cancers of the colorectum. GUT 2004, 53, 1137-1144. [CrossRef]

34. Esteller, M.; Sparks, A.; Toyota, M.; Sanchez-Cespedes, M.; Capella, G.; Peinado, M.A.; Gonzalez, S.; Tarafa, G.; Sidransky, D.; Meltzer, S.J.; et al. Analysis of adenomatous polyposis coli promoter hypermethylation in human cancer. Cancer Res. 2000, 60, 4366-4371.

35. Nosho, K.; Irahara, N.; Shima, K.; Kure, S.; Kirkner, G.J.; Schernhammer, E.S.; Hazra, A.; Hunter, D.J.; Quackenbush, J.; Spiegelman, D.; et al. Comprehensive biostatistical analysis of CpG island methylator phenotype in colorectal cancer using a large population-based sample. PLoS ONE 2008, 3, e3698. [CrossRef]

36. Ogino, S.; Goel, A. Molecular classification and correlates in colorectal cancer. J. Mol. Diagn 2008, 10, 13-27. [CrossRef] [PubMed]

37. Ogino, S.; Chan, A.T.; Fuchs, C.S.; Giovannucci, E. Molecular pathological epidemiology of colorectal neoplasia: An emerging transdisciplinary and interdisciplinary field. GUT 2011, 60, 397-411. [CrossRef]

38. Miranda, E.; Bianchi, P.; Destro, A.; Morenghi, E.; Malesci, A.; Santoro, A.; Laghi, L.; Roncalli, M. Genetic and epigenetic alterations in primary colorectal cancers and related lymph node and liver metastases. Cancer 2013, 119, 266-276. [CrossRef]

39. Sjoblom, T.; Jones, S.; Wood, L.D.; Parsons, D.W.; Lin, J.; Barber, T.D.; Mandelker, D.; Leary, R.J.; Ptak, J.; Silliman, N.; et al. The consensus coding sequences of human breast and colorectal cancers. Science 2006, 314, 268-274. [CrossRef] [PubMed]

40. Wood, L.D.; Parsons, D.W.; Jones, S.; Lin, J.; Sjoblom, T.; Leary, R.J.; Shen, D.; Boca, S.M.; Barber, T.; Ptak, J.; et al. The genomic landscapes of human breast and colorectal cancers. Science 2007, 318, 1108-1113. [CrossRef]

41. Guinney, J.; Dienstmann, R.; Wang, X.; de Reynies, A.; Schlicker, A.; Soneson, C.; Marisa, L.; Roepman, P.; Nyamundanda, G.; Angelino, P.; et al. The consensus molecular subtypes of colorectal cancer. Nat. Med. 2015, 21, 1350-1356. [CrossRef]

42. Isella, C.; Terrasi, A.; Bellomo, S.E.; Petti, C.; Galatola, G.; Muratore, A.; Mellano, A.; Senetta, R.; Cassenti, A.; Sonetto, C.; et al. Stromal contribution to the colorectal cancer transcriptome. Nat. Genet. 2015, 47, 312-319. [CrossRef]

43. Isella, C.; Brundu, F.; Bellomo, S.E.; Galimi, F.; Zanella, E.; Porporato, R.; Petti, C.; Fiori, A.; Orzan, F.; Senetta, R.; et al. Selective analysis of cancer-cell intrinsic transcriptional traits defines novel clinically relevant subtypes of colorectal cancer. Nat. Commun. 2017, 8, 15107. [CrossRef]

44. Celesti, G.; Di Caro, G.; Bianchi, P.; Grizzi, F.; Basso, G.; Marchesi, F.; Doni, A.; Marra, G.; Roncalli, M.; Mantovani, A.; et al. Presence of Twist1-positive neoplastic cells in the stroma of chromosome-unstable colorectal tumors. Gastroenterology 2013, 145, 647-657.e615. [CrossRef]

45. Galon, J.; Costes, A.; Sanchez-Cabo, F.; Kirilovsky, A.; Mlecnik, B.; Lagorce-Pages, C.; Tosolini, M.; Camus, M.; Berger, A.; Wind, P.; et al. Type, density, and location of immune cells within human colorectal tumors predict clinical outcome. Science 2006, 313, 1960-1964. [CrossRef] [PubMed] 
46. Di Caro, G.; Marchesi, F.; Laghi, L.; Grizzi, F. Immune cells: Plastic players along colorectal cancer progression. J. Cell Mol. Med. 2013, 17, 1088-1095. [CrossRef] [PubMed]

47. Grizzi, F.; Bianchi, P.; Malesci, A.; Laghi, L. Prognostic value of innate and adaptive immunity in colorectal cancer. World J. Gastroenterol. 2013, 19, 174-184. [CrossRef] [PubMed]

48. Angelova, M.; Mlecnik, B.; Vasaturo, A.; Bindea, G.; Fredriksen, T.; Lafontaine, L.; Buttard, B.; Morgand, E.; Bruni, D.; JouretMourin, A.; et al. Evolution of Metastases in Space and Time under Immune Selection. Cell 2018, 175, 751-765.e716. [CrossRef]

49. Laghi, L.; Bianchi, P.; Miranda, E.; Balladore, E.; Pacetti, V.; Grizzi, F.; Allavena, P.; Torri, V.; Repici, A.; Santoro, A.; et al. CD3+ cells at the invasive margin of deeply invading (pT3-T4) colorectal cancer and risk of post-surgical metastasis: A longitudinal study. Lancet Oncol. 2009, 10, 877-884. [CrossRef]

50. Galon, J.; Angell, H.K.; Bedognetti, D.; Marincola, F.M. The continuum of cancer immunosurveillance: Prognostic, predictive, and mechanistic signatures. Immunity 2013, 39, 11-26. [CrossRef]

51. Fridman, W.H.; Pages, F.; Sautes-Fridman, C.; Galon, J. The immune contexture in human tumours: Impact on clinical outcome. Nat. Rev. Cancer 2012, 12, 298-306. [CrossRef]

52. Galon, J.; Pages, F.; Marincola, F.M.; Thurin, M.; Trinchieri, G.; Fox, B.A.; Gajewski, T.F.; Ascierto, P.A. The immune score as a new possible approach for the classification of cancer. J. Transl Med. 2012, 10, 1. [CrossRef]

53. Galon, J.; Mlecnik, B.; Bindea, G.; Angell, H.K.; Berger, A.; Lagorce, C.; Lugli, A.; Zlobec, I.; Hartmann, A.; Bifulco, C.; et al. Towards the introduction of the 'Immunoscore' in the classification of malignant tumours. J. Pathol. 2014, 232, 199-209. [CrossRef] [PubMed]

54. Schreiber, R.D.; Old, L.J.; Smyth, M.J. Cancer immunoediting: Integrating immunity's roles in cancer suppression and promotion. Science 2011, 331, 1565-1570. [CrossRef]

55. Vesely, M.D.; Kershaw, M.H.; Schreiber, R.D.; Smyth, M.J. Natural innate and adaptive immunity to cancer. Annu. Rev. Immunol. 2011, 29, 235-271. [CrossRef] [PubMed]

56. Grivennikov, S.I.; Greten, F.R.; Karin, M. Immunity, inflammation, and cancer. Cell 2010, 140, 883-899. [CrossRef] [PubMed]

57. Hanahan, D.; Weinberg, R.A. Hallmarks of cancer: The next generation. Cell 2011, 144, 646-674. [CrossRef] [PubMed]

58. Mantovani, A.; Allavena, P.; Sica, A.; Balkwill, F. Cancer-related inflammation. Nature 2008, 454, 436-444. [CrossRef] [PubMed]

59. Coussens, L.M.; Zitvogel, L.; Palucka, A.K. Neutralizing tumor-promoting chronic inflammation: A magic bullet? Science 2013, 339, 286-291. [CrossRef] [PubMed]

60. Greten, F.R.; Grivennikov, S.I. Inflammation and Cancer: Triggers, Mechanisms, and Consequences. Immunity 2019, 51, 27-41. [CrossRef]

61. Zhang, L.; Li, Z.; Skrzypczynska, K.M.; Fang, Q.; Zhang, W.; O’Brien, S.A.; He, Y.; Wang, L.; Zhang, Q.; Kim, A.; et al. Single-Cell Analyses Inform Mechanisms of Myeloid-Targeted Therapies in Colon Cancer. Cell 2020, 181, 442-459.e429. [CrossRef] [PubMed]

62. Chen, D.S.; Mellman, I. Oncology meets immunology: The cancer-immunity cycle. Immunity 2013, 39, 1-10. [CrossRef] [PubMed]

63. Fridman, W.H.; Zitvogel, L.; Sautes-Fridman, C.; Kroemer, G. The immune contexture in cancer prognosis and treatment. Nat. Rev. Clin. Oncol. 2017, 14, 717-734. [CrossRef]

64. Mikucki, M.E.; Fisher, D.T.; Matsuzaki, J.; Skitzki, J.J.; Gaulin, N.B.; Muhitch, J.B.; Ku, A.W.; Frelinger, J.G.; Odunsi, K.; Gajewski, T.F.; et al. Non-redundant requirement for CXCR3 signalling during tumoricidal T-cell trafficking across tumour vascular checkpoints. Nat. Commun. 2015, 6, 7458. [CrossRef] [PubMed]

65. Murray, P.J.; Allen, J.E.; Biswas, S.K.; Fisher, E.A.; Gilroy, D.W.; Goerdt, S.; Gordon, S.; Hamilton, J.A.; Ivashkiv, L.B.; Lawrence, T.; et al. Macrophage activation and polarization: Nomenclature and experimental guidelines. Immunity 2014, 41, 14-20. [CrossRef]

66. Bain, C.C.; Bravo-Blas, A.; Scott, C.L.; Perdiguero, E.G.; Geissmann, F.; Henri, S.; Malissen, B.; Osborne, L.C.; Artis, D.; Mowat, A.M. Constant replenishment from circulating monocytes maintains the macrophage pool in the intestine of adult mice. Nat. Immunol. 2014, 15, 929-937. [CrossRef]

67. Eaden, J.A.; Abrams, K.R.; Mayberry, J.F. The risk of colorectal cancer in ulcerative colitis: A meta-analysis. Gut 2001, 48, 526-535. [CrossRef]

68. Grivennikov, S.I.; Wang, K.; Mucida, D.; Stewart, C.A.; Schnabl, B.; Jauch, D.; Taniguchi, K.; Yu, G.Y.; Osterreicher, C.H.; Hung, K.E.; et al. Adenoma-linked barrier defects and microbial products drive IL-23/IL-17-mediated tumour growth. Nature 2012, 491, 254-258. [CrossRef]

69. Shaked, H.; Hofseth, L.J.; Chumanevich, A.; Chumanevich, A.A.; Wang, J.; Wang, Y.; Taniguchi, K.; Guma, M.; Shenouda, S.; Clevers, H.; et al. Chronic epithelial NF-kappaB activation accelerates APC loss and intestinal tumor initiation through iNOS up-regulation. Proc. Natl. Acad. Sci. USA 2012, 109, 14007-14012. [CrossRef]

70. Dmitrieva-Posocco, O.; Dzutsev, A.; Posocco, D.F.; Hou, V.; Yuan, W.; Thovarai, V.; Mufazalov, I.A.; Gunzer, M.; Shilovskiy, I.P.; Khaitov, M.R.; et al. Cell-Type-Specific Responses to Interleukin-1 Control Microbial Invasion and Tumor-Elicited Inflammation in Colorectal Cancer. Immunity 2019, 50, 166-180.e167. [CrossRef]

71. West, N.R.; McCuaig, S.; Franchini, F.; Powrie, F. Emerging cytokine networks in colorectal cancer. Nat. Rev. Immunol. 2015, 15, 615-629. [CrossRef] [PubMed]

72. Lasry, A.; Zinger, A.; Ben-Neriah, Y. Inflammatory networks underlying colorectal cancer. Nat. Immunol. 2016, 17, 230-240. [CrossRef] [PubMed]

73. Mager, L.F.; Wasmer, M.H.; Rau, T.T.; Krebs, P. Cytokine-Induced Modulation of Colorectal Cancer. Front. Oncol. 2016, 6, 96. [CrossRef] 
74. Trinchieri, G. Cancer and inflammation: An old intuition with rapidly evolving new concepts. Annu. Rev. Immunol. 2012, 30, 677-706. [CrossRef]

75. McCuaig, S.; Barras, D.; Mann, E.H.; Friedrich, M.; Bullers, S.J.; Janney, A.; Garner, L.C.; Domingo, E.; Koelzer, V.H.; Delorenzi, M.; et al. The Interleukin 22 Pathway Interacts with Mutant KRAS to Promote Poor Prognosis in Colon Cancer. Clin. Cancer Res. 2020, 26, 4313-4325. [CrossRef] [PubMed]

76. Mlecnik, B.; Bindea, G.; Angell, H.K.; Sasso, M.S.; Obenauf, A.C.; Fredriksen, T.; Lafontaine, L.; Bilocq, A.M.; Kirilovsky, A.; Tosolini, M.; et al. Functional network pipeline reveals genetic determinants associated with in situ lymphocyte proliferation and survival of cancer patients. Sci. Transl. Med. 2014, 6, 228ra237. [CrossRef]

77. Calon, A.; Lonardo, E.; Berenguer-Llergo, A.; Espinet, E.; Hernando-Momblona, X.; Iglesias, M.; Sevillano, M.; Palomo-Ponce, S.; Tauriello, D.V.; Byrom, D.; et al. Stromal gene expression defines poor-prognosis subtypes in colorectal cancer. Nat. Genet. 2015, 47, 320-329. [CrossRef]

78. Di Caro, G.; Carvello, M.; Pesce, S.; Erreni, M.; Marchesi, F.; Todoric, J.; Sacchi, M.; Montorsi, M.; Allavena, P.; Spinelli, A. Circulating Inflammatory Mediators as Potential Prognostic Markers of Human Colorectal Cancer. PLoS ONE 2016, 11, e0148186. [CrossRef]

79. Gunawardene, A.; Dennett, E.; Larsen, P. Prognostic value of multiple cytokine analysis in colorectal cancer: A systematic review. J. Gastrointest. Oncol. 2019, 10, 134-143. [CrossRef]

80. Boakye, D.; Jansen, L.; Schottker, B.; Jansen, E.; Schneider, M.; Halama, N.; Gao, X.; Chang-Claude, J.; Hoffmeister, M.; Brenner, H. Blood markers of oxidative stress are strongly associated with poorer prognosis in colorectal cancer patients. Int. J. Cancer 2020, 147, 2373-2386. [CrossRef]

81. Mlecnik, B.; Bindea, G.; Angell, H.K.; Maby, P.; Angelova, M.; Tougeron, D.; Church, S.E.; Lafontaine, L.; Fischer, M.; Fredriksen, T.; et al. Integrative Analyses of Colorectal Cancer Show Immunoscore Is a Stronger Predictor of Patient Survival Than Microsatellite Instability. Immunity 2016, 44, 698-711. [CrossRef] [PubMed]

82. Zhang, L.; Yu, X.; Zheng, L.; Zhang, Y.; Li, Y.; Fang, Q.; Gao, R.; Kang, B.; Zhang, Q.; Huang, J.Y.; et al. Lineage tracking reveals dynamic relationships of T cells in colorectal cancer. Nature 2018, 564, 268-272. [CrossRef] [PubMed]

83. Salama, P.; Phillips, M.; Grieu, F.; Morris, M.; Zeps, N.; Joseph, D.; Platell, C.; Iacopetta, B. Tumor-infiltrating FOXP3+ T regulatory cells show strong prognostic significance in colorectal cancer. J. Clin. Oncol. 2009, 27, 186-192. [CrossRef] [PubMed]

84. Nakagawa, K.; Tanaka, K.; Homma, Y.; Nojiri, K.; Kumamoto, T.; Takeda, K.; Endo, I. Low infiltration of peritumoral regulatory T cells predicts worse outcome following resection of colorectal liver metastases. Ann. Surg. Oncol. 2015, 22, 180-186. [CrossRef] [PubMed]

85. Cavalleri, T.; Bianchi, P.; Basso, G.; Celesti, G.; Grizzi, F.; Bossi, P.; Greco, L.; Pitrone, C.; Valtorta, E.; Mauri, G.; et al. Combined Low Densities of FoxP3(+) and CD3(+) Tumor-Infiltrating Lymphocytes Identify Stage II Colorectal Cancer at High Risk of Progression. Cancer Immunol. Res. 2019, 7, 751-758. [CrossRef]

86. Whiteside, T.L. What are regulatory T cells (Treg) regulating in cancer and why? Semin Cancer Biol. 2012, 22, 327-334. [CrossRef]

87. Coppola, D.; Nebozhyn, M.; Khalil, F.; Dai, H.; Yeatman, T.; Loboda, A.; Mule, J.J. Unique ectopic lymph node-like structures present in human primary colorectal carcinoma are identified by immune gene array profiling. Am. J. Pathol. 2011, 179, 37-45. [CrossRef]

88. Di Caro, G.; Bergomas, F.; Grizzi, F.; Doni, A.; Bianchi, P.; Malesci, A.; Laghi, L.; Allavena, P.; Mantovani, A.; Marchesi, F. Occurrence of tertiary lymphoid tissue is associated with T-cell infiltration and predicts better prognosis in early-stage colorectal cancers. Clin. Cancer Res. 2014, 20, 2147-2158. [CrossRef]

89. Sautes-Fridman, C.; Petitprez, F.; Calderaro, J.; Fridman, W.H. Tertiary lymphoid structures in the era of cancer immunotherapy. Nat. Rev. Cancer 2019, 19, 307-325. [CrossRef] [PubMed]

90. Castino, G.F.; Cortese, N.; Capretti, G.; Serio, S.; Di Caro, G.; Mineri, R.; Magrini, E.; Grizzi, F.; Cappello, P.; Novelli, F.; et al. Spatial distribution of B cells predicts prognosis in human pancreatic adenocarcinoma. Oncoimmunology 2016, 5, e1085147. [CrossRef] [PubMed]

91. Shalapour, S.; Font-Burgada, J.; Di Caro, G.; Zhong, Z.; Sanchez-Lopez, E.; Dhar, D.; Willimsky, G.; Ammirante, M.; Strasner, A.; Hansel, D.E.; et al. Immunosuppressive plasma cells impede T-cell-dependent immunogenic chemotherapy. Nature 2015, 521, 94-98. [CrossRef]

92. Biswas, S.K.; Allavena, P.; Mantovani, A. Tumor-associated macrophages: Functional diversity, clinical significance, and open questions. Semin Immunopathol. 2013, 35, 585-600. [CrossRef] [PubMed]

93. Noy, R.; Pollard, J.W. Tumor-associated macrophages: From mechanisms to therapy. Immunity 2014, 41, 49-61. [CrossRef] [PubMed]

94. DeNardo, D.G.; Ruffell, B. Macrophages as regulators of tumour immunity and immunotherapy. Nat. Rev. Immunol. 2019, 19, 369-382. [CrossRef] [PubMed]

95. Liu, Q.; Yang, C.; Wang, S.; Shi, D.; Wei, C.; Song, J.; Lin, X.; Dou, R.; Bai, J.; Xiang, Z.; et al. Wnt5a-induced M2 polarization of tumor-associated macrophages via IL-10 promotes colorectal cancer progression. Cell Commun. Signal. 2020, 18, 51. [CrossRef]

96. Forssell, J.; Oberg, A.; Henriksson, M.L.; Stenling, R.; Jung, A.; Palmqvist, R. High macrophage infiltration along the tumor front correlates with improved survival in colon cancer. Clin. Cancer Res. 2007, 13, 1472-1479. [CrossRef] [PubMed]

97. Zhou, Q.; Peng, R.Q.; Wu, X.J.; Xia, Q.; Hou, J.H.; Ding, Y.; Zhou, Q.M.; Zhang, X.; Pang, Z.Z.; Wan, D.S.; et al. The density of macrophages in the invasive front is inversely correlated to liver metastasis in colon cancer. J. Transl Med. 2010, 8, 13. [CrossRef] 
98. Zhang, Q.W.; Liu, L.; Gong, C.Y.; Shi, H.S.; Zeng, Y.H.; Wang, X.Z.; Zhao, Y.W.; Wei, Y.Q. Prognostic significance of tumorassociated macrophages in solid tumor: A meta-analysis of the literature. PLoS ONE 2012, 7, e50946. [CrossRef] [PubMed]

99. Malesci, A.; Bianchi, P.; Celesti, G.; Basso, G.; Marchesi, F.; Grizzi, F.; Di Caro, G.; Cavalleri, T.; Rimassa, L.; Palmqvist, R.; et al. Tumor-associated macrophages and response to 5-fluorouracil adjuvant therapy in stage III colorectal cancer. Oncoimmunology 2017, 6, e1342918. [CrossRef]

100. Jass, J.R.; Do, K.A.; Simms, L.A.; Iino, H.; Wynter, C.; Pillay, S.P.; Searle, J.; Radford-Smith, G.; Young, J.; Leggett, B. Morphology of sporadic colorectal cancer with DNA replication errors. Gut 1998, 42, 673-679. [CrossRef]

101. Rodriguez-Bigas, M.A.; Boland, C.R.; Hamilton, S.R.; Henson, D.E.; Jass, J.R.; Khan, P.M.; Lynch, H.; Perucho, M.; Smyrk, T.; Sobin, L.; et al. A National Cancer Institute Workshop on Hereditary Nonpolyposis Colorectal Cancer Syndrome: Meeting highlights and Bethesda guidelines. J. Natl. Cancer Inst. 1997, 89, 1758-1762. [CrossRef]

102. Perucho, M. Microsatellite instability: The mutator that mutates the other mutator. Nat. Med. 1996, 2, 630-631. [CrossRef] [PubMed]

103. Malkhosyan, S.; Rampino, N.; Yamamoto, H.; Perucho, M. Frameshift mutator mutations. Nature 1996, 382, 499-500. [CrossRef]

104. Perucho, M. Tumors with microsatellite instability: Many mutations, targets and paradoxes. Oncogene 2003, 22, 2223-2225. [CrossRef]

105. Schwitalle, Y.; Kloor, M.; Eiermann, S.; Linnebacher, M.; Kienle, P.; Knaebel, H.P.; Tariverdian, M.; Benner, A.; von Knebel Doeberitz, M. Immune response against frameshift-induced neopeptides in HNPCC patients and healthy HNPCC mutation carriers. Gastroenterology 2008, 134, 988-997. [CrossRef] [PubMed]

106. Kim, H.; Jen, J.; Vogelstein, B.; Hamilton, S.R. Clinical and pathological characteristics of sporadic colorectal carcinomas with DNA replication errors in microsatellite sequences. Am. J. Pathol. 1994, 145, 148-156.

107. Domingo, E.; Freeman-Mills, L.; Rayner, E.; Glaire, M.; Briggs, S.; Vermeulen, L.; Fessler, E.; Medema, J.P.; Boot, A.; Morreau, H.; et al. Somatic POLE proofreading domain mutation, immune response, and prognosis in colorectal cancer: A retrospective, pooled biomarker study. Lancet Gastroenterol. Hepatol. 2016, 1, 207-216. [CrossRef]

108. Mo, S.; Ma, X.; Li, Y.; Zhang, L.; Hou, T.; Han-Zhang, H.; Qian, J.; Cai, S.; Huang, D.; Peng, J. Somatic POLE exonuclease domain mutations elicit enhanced intratumoral immune responses in stage II colorectal cancer. J. Immunother. Cancer 2020, 8. [CrossRef]

109. Vayrynen, J.P.; Haruki, K.; Lau, M.C.; Vayrynen, S.A.; Zhong, R.; Dias Costa, A.; Borowsky, J.; Zhao, M.; Fujiyoshi, K.; Arima, K.; et al. The Prognostic Role of Macrophage Polarization in the Colorectal Cancer Microenvironment. Cancer Immunol. Res. 2021, 9 , 8-19. [CrossRef]

110. Laghi, L.; Negri, F.; Gaiani, F.; Cavalleri, T.; Grizzi, F.; De' Angelis, G.L.; Malesci, A. Prognostic and Predictive Cross-Roads of Microsatellite Instability and Immune Response to Colon Cancer. Int. J. Mol. Sci. 2020, 21, 9680. [CrossRef]

111. Giannakis, M.; Mu, X.J.; Shukla, S.A.; Qian, Z.R.; Cohen, O.; Nishihara, R.; Bahl, S.; Cao, Y.; Amin-Mansour, A.; Yamauchi, M.; et al. Genomic Correlates of Immune-Cell Infiltrates in Colorectal Carcinoma. Cell Rep. 2016, 17, 1206. [CrossRef] [PubMed]

112. Jussila, A.; Virta, L.J.; Pukkala, E.; Farkkila, M.A. Malignancies in patients with inflammatory bowel disease: A nationwide register study in Finland. Scand. J. Gastroenterol. 2013, 48, 1405-1413. [CrossRef] [PubMed]

113. Jess, T.; Horvath-Puho, E.; Fallingborg, J.; Rasmussen, H.H.; Jacobsen, B.A. Cancer risk in inflammatory bowel disease according to patient phenotype and treatment: A Danish population-based cohort study. Am. J. Gastroenterol. 2013, 108, 1869-1876. [CrossRef]

114. Kappelman, M.D.; Farkas, D.K.; Long, M.D.; Erichsen, R.; Sandler, R.S.; Sorensen, H.T.; Baron, J.A. Risk of cancer in patients with inflammatory bowel diseases: A nationwide population-based cohort study with 30 years of follow-up evaluation. Clin. Gastroenterol. Hepatol. 2014, 12, 265-273.e261. [CrossRef]

115. Peneau, A.; Savoye, G.; Turck, D.; Dauchet, L.; Fumery, M.; Salleron, J.; Lerebours, E.; Ligier, K.; Vasseur, F.; Dupas, J.L.; et al. Mortality and cancer in pediatric-onset inflammatory bowel disease: A population-based study. Am. J. Gastroenterol. 2013, 108, 1647-1653. [CrossRef]

116. Duricova, D.; Fumery, M.; Annese, V.; Lakatos, P.L.; Peyrin-Biroulet, L.; Gower-Rousseau, C. The natural history of Crohn's disease in children: A review of population-based studies. Eur. J. Gastroenterol. Hepatol. 2017, 29, 125-134. [CrossRef]

117. Iannone, A.; Ruospo, M.; Wong, G.; Principi, M.; Barone, M.; Strippoli, G.F.M.; Di Leo, A. Chromoendoscopy for Surveillance in Ulcerative Colitis and Crohn's Disease: A Systematic Review of Randomized Trials. Clin. Gastroenterol. Hepatol. 2017, 15, 1684-1697.e1611. [CrossRef] [PubMed]

118. Lutgens, M.W.; van Oijen, M.G.; van der Heijden, G.J.; Vleggaar, F.P.; Siersema, P.D.; Oldenburg, B. Declining risk of colorectal cancer in inflammatory bowel disease: An updated meta-analysis of population-based cohort studies. Inflamm Bowel. Dis. 2013, 19, 789-799. [CrossRef]

119. Choi, C.R.; Bakir, I.A.; Hart, A.L.; Graham, T.A. Clonal evolution of colorectal cancer in IBD. Nat. Rev. Gastroenterol. Hepatol. 2017, 14, 218-229. [CrossRef]

120. Bopanna, S.; Roy, M.; Das, P.; Dattagupta, S.; Sreenivas, V.; Mouli, V.P.; Kedia, S.; Dhingra, R.; Pradhan, R.; Kumar, N.S.; et al. Role of random biopsies in surveillance of dysplasia in ulcerative colitis patients with high risk of colorectal cancer. Intest. Res. 2016, 14, 264-269. [CrossRef]

121. Dulai, P.S.; Sandborn, W.J.; Gupta, S. Colorectal Cancer and Dysplasia in Inflammatory Bowel Disease: A Review of Disease Epidemiology, Pathophysiology, and Management. Cancer Prev. Res. 2016, 9, 887-894. [CrossRef] [PubMed] 
122. Fornaro, R.; Caratto, M.; Caratto, E.; Caristo, G.; Fornaro, F.; Giovinazzo, D.; Sticchi, C.; Casaccia, M.; Andorno, E. Colorectal Cancer in Patients With Inflammatory Bowel Disease: The Need for a Real Surveillance Program. Clin. Colorectal. Cancer 2016, 15, 204-212. [CrossRef] [PubMed]

123. Jewel Samadder, N.; Valentine, J.F.; Guthery, S.; Singh, H.; Bernstein, C.N.; Wan, Y.; Wong, J.; Boucher, K.; Pappas, L.; Rowe, K.; et al. Colorectal Cancer in Inflammatory Bowel Diseases: A Population-Based Study in Utah. Dig. Dis. Sci. 2017, 62, $2126-2132$. [CrossRef] [PubMed]

124. Hata, K.; Kishikawa, J.; Anzai, H.; Shinagawa, T.; Kazama, S.; Ishii, H.; Nozawa, H.; Kawai, K.; Kiyomatsu, T.; Tanaka, J.; et al. Surveillance colonoscopy for colitis-associated dysplasia and cancer in ulcerative colitis patients. Dig. Endosc. 2016, 28, 260-265. [CrossRef] [PubMed]

125. Han, Y.D.; Al Bandar, M.H.; Dulskas, A.; Cho, M.S.; Hur, H.; Min, B.S.; Lee, K.Y.; Kim, N.K. Prognosis of ulcerative colitis colorectal cancer vs. sporadic colorectal cancer: Propensity score matching analysis. BMC Surg. 2017, 17, 28. [CrossRef] [PubMed]

126. Sengupta, N.; Yee, E.; Feuerstein, J.D. Colorectal Cancer Screening in Inflammatory Bowel Disease. Dig. Dis. Sci. 2016, 61, 980-989. [CrossRef] [PubMed]

127. Annese, V.; Beaugerie, L.; Egan, L.; Biancone, L.; Bolling, C.; Brandts, C.; Dierickx, D.; Dummer, R.; Fiorino, G.; Gornet, J.M.; et al. European Evidence-based Consensus: Inflammatory Bowel Disease and Malignancies. J. Crohns Colitis 2015, 9, 945-965. [CrossRef]

128. Fumery, M.; Pineton de Chambrun, G.; Stefanescu, C.; Buisson, A.; Bressenot, A.; Beaugerie, L.; Amiot, A.; Altwegg, R.; Savoye, G.; Abitbol, V.; et al. Detection of Dysplasia or Cancer in 3.5\% of Patients With Inflammatory Bowel Disease and Colonic Strictures. Clin. Gastroenterol. Hepatol. 2015, 13, 1770-1775. [CrossRef]

129. Sonnenberg, A.; Genta, R.M. Epithelial Dysplasia and Cancer in IBD Strictures. J. Crohns Colitis 2015, 9, 769-775. [CrossRef]

130. Popp, C.; Nichita, L.; Voiosu, T.; Bastian, A.; Cioplea, M.; Micu, G.; Pop, G.; Sticlaru, L.; Bengus, A.; Voiosu, A.; et al. Expression Profile of p53 and p21 in Large Bowel Mucosa as Biomarkers of Inflammatory-Related Carcinogenesis in Ulcerative Colitis. Dis. Markers 2016, 2016, 3625279. [CrossRef]

131. Yamamoto, M.; Matsumoto, S. Gut microbiota and colorectal cancer. Genes Environ. 2016, 38, 11. [CrossRef] [PubMed]

132. Kanauchi, O.; Mitsuyama, K.; Andoh, A. The new prophylactic strategy for colon cancer in inflammatory bowel disease by modulating microbiota. Scand. J. Gastroenterol. 2013, 48, 387-400. [CrossRef] [PubMed]

133. Messaritakis, I.; Koulouridi, A.; Sfakianaki, M.; Vogiatzoglou, K.; Gouvas, N.; Athanasakis, E.; Tsiaoussis, J.; Xynos, E.; Mavroudis, D.; Tzardi, M.; et al. The Role of Vitamin D Receptor Gene Polymorphisms in Colorectal Cancer Risk. Cancers 2020, $12,1379$. [CrossRef] [PubMed]

134. Markowska, A.; Antoszczak, M.; Kojs, Z.; Bednarek, W.; Markowska, J.; Huczynski, A. Role of vitamin D3 in selected malignant neoplasms. Nutrition 2020, 79-80, 110964. [CrossRef]

135. Sadeghi, H.; Nazemalhosseini-Mojarad, E.; Sahebi, U.; Fazeli, E.; Azizi-Tabesh, G.; Yassaee, V.R.; Savabkar, S.; Asadzadeh Aghdaei, H.; Zali, M.R.; Mirfakhraie, R. Novel long noncoding RNAs upregulation may have synergistic effects on the CYP24A1 and PFDN4 biomarker role in human colorectal cancer. J. Cell Physiol. 2021, 236, 2051-2057. [CrossRef]

136. Sadeghi, H.; Heiat, M. A novel circular RNA hsa_circ_0060927 may serve as a potential diagnostic biomarker for human colorectal cancer. Mol. Biol Rep. 2020, 47, 6649-6655. [CrossRef]

137. Flores, O.; Wang, Z.; Knudsen, K.E.; Burnstein, K.L. Nuclear targeting of cyclin-dependent kinase 2 reveals essential roles of cyclin-dependent kinase 2 localization and cyclin E in vitamin D-mediated growth inhibition. Endocrinology 2010, 151, 896-908. [CrossRef]

138. Jensen, S.S.; Madsen, M.W.; Lukas, J.; Binderup, L.; Bartek, J. Inhibitory effects of 1alpha,25-dihydroxyvitamin D(3) on the G(1)-S phase-controlling machinery. Mol. Endocrinol. 2001, 15, 1370-1380. [CrossRef]

139. Wang, P.; Qin, X.; Liu, M.; Wang, X. The burgeoning role of cytochrome P450-mediated vitamin D metabolites against colorectal cancer. Pharmacol. Res. 2018, 133, 9-20. [CrossRef]

140. Feldman, D.; Krishnan, A.V.; Swami, S.; Giovannucci, E.; Feldman, B.J. The role of vitamin D in reducing cancer risk and progression. Nat. Rev. Cancer 2014, 14, 342-357. [CrossRef]

141. Kure, S.; Nosho, K.; Baba, Y.; Irahara, N.; Shima, K.; Ng, K.; Meyerhardt, J.A.; Giovannucci, E.L.; Fuchs, C.S.; Ogino, S. Vitamin D receptor expression is associated with PIK3CA and KRAS mutations in colorectal cancer. Cancer Epidemiol. Biomarkers Prev. 2009, 18, 2765-2772. [CrossRef] [PubMed]

142. Mocellin, S. Vitamin D and cancer: Deciphering the truth. Biochim Biophys Acta 2011, 1816, 172-178. [CrossRef]

143. Gandini, S.; Boniol, M.; Haukka, J.; Byrnes, G.; Cox, B.; Sneyd, M.J.; Mullie, P.; Autier, P. Meta-analysis of observational studies of serum 25-hydroxyvitamin D levels and colorectal, breast and prostate cancer and colorectal adenoma. Int. J. Cancer 2011, 128, 1414-1424. [CrossRef] [PubMed]

144. Pendas-Franco, N.; Garcia, J.M.; Pena, C.; Valle, N.; Palmer, H.G.; Heinaniemi, M.; Carlberg, C.; Jimenez, B.; Bonilla, F.; Munoz, A.; et al. DICKKOPF-4 is induced by TCF/beta-catenin and upregulated in human colon cancer, promotes tumour cell invasion and angiogenesis and is repressed by 1alpha,25-dihydroxyvitamin D3. Oncogene 2008, 27, 4467-4477. [CrossRef] [PubMed]

145. Meeker, S.; Seamons, A.; Maggio-Price, L.; Paik, J. Protective links between vitamin D, inflammatory bowel disease and colon cancer. World J. Gastroenterol. 2016, 22, 933-948. [CrossRef] 
146. Shintani, T.; Rosli, S.N.Z.; Takatsu, F.; Choon, Y.F.; Hayashido, Y.; Toratani, S.; Usui, E.; Okamoto, T. Eldecalcitol (ED-71), an analog of 1alpha,25-dihydroxyvitamin D3 as a potential anti-cancer agent for oral squamous cell carcinomas. J. Steroid Biochem. Mol. Biol. 2016, 164, 79-84. [CrossRef] [PubMed]

147. Bandera Merchan, B.; Morcillo, S.; Martin-Nunez, G.; Tinahones, F.J.; Macias-Gonzalez, M. The role of vitamin D and VDR in carcinogenesis: Through epidemiology and basic sciences. J. Steroid Biochem. Mol. Biol. 2017, 167, 203-218. [CrossRef]

148. Wesselink, E.; Balvers, M.; Bours, M.J.L.; de Wilt, J.H.W.; Witkamp, R.F.; van Baar, H.; Geijsen, A.; van Halteren, H.; Keulen, E.T.P.; Kok, D.E.; et al. The association between circulating levels of vitamin D and inflammatory markers in the first 2 years after colorectal cancer diagnosis. Therap Adv. Gastroenterol. 2020, 13, 1756284820923922. [CrossRef]

149. Krishnan, A.V.; Feldman, D. Mechanisms of the anti-cancer and anti-inflammatory actions of vitamin D. Annu. Rev. Pharmacol. Toxicol. 2011, 51, 311-336. [CrossRef]

150. Karin, M.; Lin, A. NF-kappaB at the crossroads of life and death. Nat. Immunol. 2002, 3, 221-227. [CrossRef]

151. Al-Jaderi, Z.; Maghazachi, A.A. Effects of vitamin D3, calcipotriol and FTY720 on the expression of surface molecules and cytolytic activities of human natural killer cells and dendritic cells. Toxins 2013, 5, 1932-1947. [CrossRef] [PubMed]

152. Theodoratou, E.; Farrington, S.M.; Tenesa, A.; McNeill, G.; Cetnarskyj, R.; Barnetson, R.A.; Porteous, M.E.; Dunlop, M.G.; Campbell, H. Modification of the inverse association between dietary vitamin D intake and colorectal cancer risk by a FokI variant supports a chemoprotective action of Vitamin D intake mediated through VDR binding. Int. J. Cancer 2008, 123, 2170-2179. [CrossRef] [PubMed]

153. Xu, Y.; He, B.; Pan, Y.; Deng, Q.; Sun, H.; Li, R.; Gao, T.; Song, G.; Wang, S. Systematic review and meta-analysis on vitamin D receptor polymorphisms and cancer risk. Tumour Biol. 2014, 35, 4153-4169. [CrossRef] [PubMed]

154. Zhang, X.; Fang, Y.J.; Feng, X.L.; Abulimiti, A.; Huang, C.Y.; Luo, H.; Zhang, C.X. Interactions Between Vitamin D and Calcium Intake, Vitamin D Receptor Genetic Polymorphisms, and Colorectal Cancer Risk. Dig. Dis. Sci. 2020. [CrossRef]

155. Yu, K.; Yang, J.; Jiang, Y.; Song, R.; Lu, Q. Vitamin D receptor BsmI polymorphism and colorectal cancer risk: An updated analysis. Asian Pac. J. Cancer Prev. 2014, 15, 4801-4807. [CrossRef]

156. Slattery, M.L.; Wolff, R.K.; Curtin, K.; Fitzpatrick, F.; Herrick, J.; Potter, J.D.; Caan, B.J.; Samowitz, W.S. Colon tumor mutations and epigenetic changes associated with genetic polymorphism: Insight into disease pathways. Mutat Res. 2009, 660, 12-21. [CrossRef] [PubMed]

157. Keum, N.; Giovannucci, E. Vitamin D supplements and cancer incidence and mortality: A meta-analysis. Br. J. Cancer 2014, 111, 976-980. [CrossRef]

158. Wu, K.; Feskanich, D.; Fuchs, C.S.; Willett, W.C.; Hollis, B.W.; Giovannucci, E.L. A nested case control study of plasma 25hydroxyvitamin D concentrations and risk of colorectal cancer. J. Natl. Cancer Inst. 2007, 99, 1120-1129. [CrossRef]

159. Jenab, M.; Bueno-de-Mesquita, H.B.; Ferrari, P.; van Duijnhoven, F.J.; Norat, T.; Pischon, T.; Jansen, E.H.; Slimani, N.; Byrnes, G.; Rinaldi, S.; et al. Association between pre-diagnostic circulating vitamin D concentration and risk of colorectal cancer in European populations:a nested case-control study. BMJ 2010, 340, b5500. [CrossRef]

160. Lee, J.E.; Li, H.; Chan, A.T.; Hollis, B.W.; Lee, I.M.; Stampfer, M.J.; Wu, K.; Giovannucci, E.; Ma, J. Circulating levels of vitamin D and colon and rectal cancer: The Physicians' Health Study and a meta-analysis of prospective studies. Cancer Prev. Res. 2011, 4, 735-743. [CrossRef]

161. Yin, L.; Grandi, N.; Raum, E.; Haug, U.; Arndt, V.; Brenner, H. Meta-analysis: Longitudinal studies of serum vitamin D and colorectal cancer risk. Aliment. Pharmacol. Ther. 2009, 30, 113-125. [CrossRef]

162. Li, M.; Chen, P.; Li, J.; Chu, R.; Xie, D.; Wang, H. Review: The impacts of circulating 25-hydroxyvitamin D levels on cancer patient outcomes: A systematic review and meta-analysis. J. Clin. Endocrinol. Metab. 2014, 99, 2327-2336. [CrossRef] [PubMed]

163. Yuan, C.; Song, M.; Zhang, Y.; Wolpin, B.M.; Meyerhardt, J.A.; Ogino, S.; Hollis, B.W.; Chan, A.T.; Fuchs, C.S.; Wu, K.; et al. Prediagnostic Circulating Concentrations of Vitamin D Binding Protein and Survival among Patients with Colorectal Cancer. Cancer Epidemiol. Biomarkers Prev. 2020, 29, 2323-2331. [CrossRef] [PubMed]

164. Vaughan-Shaw, P.G.; Buijs, L.F.; Blackmur, J.P.; Theodoratou, E.; Zgaga, L.; Din, F.V.N.; Farrington, S.M.; Dunlop, M.G. The effect of vitamin D supplementation on survival in patients with colorectal cancer: Systematic review and meta-analysis of randomised controlled trials. Br. J. Cancer 2020, 123, 1705-1712. [CrossRef] [PubMed]

165. Prevarskaya, N.; Skryma, R.; Shuba, Y. Ion Channels in Cancer: Are Cancer Hallmarks Oncochannelopathies? Physiol. Rev. 2018, 98, 559-621. [CrossRef]

166. Kim, B.J.; Kim, S.Y.; Lee, S.; Jeon, J.H.; Matsui, H.; Kwon, Y.K.; Kim, S.J.; So, I. The role of transient receptor potential channel blockers in human gastric cancer cell viability. Can. J. Physiol. Pharmacol. 2012, 90, 175-186. [CrossRef] [PubMed]

167. Xie, B.; Zhao, R.; Bai, B.; Wu, Y.; Xu, Y.; Lu, S.; Fang, Y.; Wang, Z.; Maswikiti, E.P.; Zhou, X.; et al. Identification of key tumorigenesisrelated genes and their microRNAs in colon cancer. Oncol. Rep. 2018, 40, 3551-3560. [CrossRef]

168. Wang, C.Y.; Lai, M.D.; Phan, N.N.; Sun, Z.; Lin, Y.C. Meta-Analysis of Public Microarray Datasets Reveals Voltage-Gated Calcium Gene Signatures in Clinical Cancer Patients. PLoS ONE 2015, 10, e0125766. [CrossRef]

169. Villalobos, C.; Sobradillo, D.; Hernandez-Morales, M.; Nunez, L. Calcium remodeling in colorectal cancer. Biochim Biophys Acta Mol. Cell Res. 2017, 1864, 843-849. [CrossRef]

170. Lipkin, M.; Newmark, H. Effect of added dietary calcium on colonic epithelial-cell proliferation in subjects at high risk for familial colonic cancer. N. Engl. J. Med. 1985, 313, 1381-1384. [CrossRef] 
171. Garland, C.; Shekelle, R.B.; Barrett-Connor, E.; Criqui, M.H.; Rossof, A.H.; Paul, O. Dietary vitamin D and calcium and risk of colorectal cancer: A 19-year prospective study in men. Lancet 1985, 1, 307-309. [CrossRef]

172. Bonovas, S.; Fiorino, G.; Lytras, T.; Malesci, A.; Danese, S. Calcium supplementation for the prevention of colorectal adenomas: A systematic review and meta-analysis of randomized controlled trials. World J. Gastroenterol. 2016, 22, 4594-4603. [CrossRef] [PubMed]

173. Newmark, H.L.; Wargovich, M.J.; Bruce, W.R. Colon cancer and dietary fat, phosphate, and calcium: A hypothesis. J. Natl. Cancer Inst. 1984, 72, 1323-1325. [PubMed]

174. Pence, B.C. Role of calcium in colon cancer prevention: Experimental and clinical studies. Mutat Res. 1993, 290, 87-95. [CrossRef]

175. Wang, W.; Yu, S.; Huang, S.; Deng, R.; Ding, Y.; Wu, Y.; Li, X.; Wang, A.; Wang, S.; Chen, W.; et al. A Complex Role for Calcium Signaling in Colorectal Cancer Development and Progression. Mol. Cancer Res. 2019, 17, 2145-2153. [CrossRef]

176. Yashiro, M. Ulcerative colitis-associated colorectal cancer. World J. Gastroenterol. 2014, 20, 16389-16397. [CrossRef]

177. Velayos, F.S.; Terdiman, J.P.; Walsh, J.M. Effect of 5-aminosalicylate use on colorectal cancer and dysplasia risk: A systematic review and metaanalysis of observational studies. Am. J. Gastroenterol. 2005, 100, 1345-1353. [CrossRef]

178. Nguyen, G.C.; Gulamhusein, A.; Bernstein, C.N. 5-aminosalicylic acid is not protective against colorectal cancer in inflammatory bowel disease: A meta-analysis of non-referral populations. Am. J. Gastroenterol. 2012, 107, 1298-1304. [CrossRef] [PubMed]

179. Cahill, C.; Gordon, P.H.; Petrucci, A.; Boutros, M. Small bowel adenocarcinoma and Crohn's disease: Any further ahead than 50 years ago? World J. Gastroenterol 2014, 20, 11486-11495. [CrossRef]

180. Gong, J.; Zhu, L.; Guo, Z.; Li, Y.; Zhu, W.; Li, N.; Li, J. Use of thiopurines and risk of colorectal neoplasia in patients with inflammatory bowel diseases: A meta-analysis. PLoS ONE 2013, 8, e81487. [CrossRef]

181. Arber, N.; Levin, B. Chemoprevention of colorectal neoplasia: The potential for personalized medicine. Gastroenterology 2008, 134, 1224-1237. [CrossRef]

182. Kune, G.A.; Kune, S.; Watson, L.F. Colorectal cancer risk, chronic illnesses, operations, and medications: Case control results from the Melbourne Colorectal Cancer Study. Cancer Res. 1988, 48, 4399-4404. [CrossRef]

183. Giovannucci, E.; Egan, K.M.; Hunter, D.J.; Stampfer, M.J.; Colditz, G.A.; Willett, W.C.; Speizer, F.E. Aspirin and the risk of colorectal cancer in women. N. Engl. J. Med. 1995, 333, 609-614. [CrossRef] [PubMed]

184. Chan, A.T.; Giovannucci, E.L.; Meyerhardt, J.A.; Schernhammer, E.S.; Wu, K.; Fuchs, C.S. Aspirin dose and duration of use and risk of colorectal cancer in men. Gastroenterology 2008, 134, 21-28. [CrossRef] [PubMed]

185. Dinakaran, D.; Sergi, C.M. Co-ingestion of aspirin and acetaminophen promoting fulminant liver failure: A critical review of Reye syndrome in the current perspective at the dawn of the 21st century. Clin. Exp. Pharmacol. Physiol. 2018, 45, 117-121. [CrossRef] [PubMed]

186. Chan, A.T.; Ogino, S.; Fuchs, C.S. Aspirin and the risk of colorectal cancer in relation to the expression of COX-2. N. Engl. J. Med. 2007, 356, 2131-2142. [CrossRef]

187. Steinbach, G.; Lynch, P.M.; Phillips, R.K.; Wallace, M.H.; Hawk, E.; Gordon, G.B.; Wakabayashi, N.; Saunders, B.; Shen, Y.; Fujimura, T.; et al. The effect of celecoxib, a cyclooxygenase-2 inhibitor, in familial adenomatous polyposis. N. Engl. J. Med. 2000, 342, 1946-1952. [CrossRef] [PubMed]

188. Burn, J.; Sheth, H.; Elliott, F.; Reed, L.; Macrae, F.; Mecklin, J.P.; Moslein, G.; McRonald, F.E.; Bertario, L.; Evans, D.G.; et al. Cancer prevention with aspirin in hereditary colorectal cancer (Lynch syndrome), 10-year follow-up and registry-based 20-year data in the CAPP2 study: A double-blind, randomised, placebo-controlled trial. Lancet 2020, 395, 1855-1863. [CrossRef]

189. Alexander, J.L.; Scott, A.J.; Pouncey, A.L.; Marchesi, J.; Kinross, J.; Teare, J. Colorectal carcinogenesis: An archetype of gut microbiota-host interaction. Ecancermedicalscience 2018, 12, 865. [CrossRef]

190. Gholizadeh, P.; Eslami, H.; Kafil, H.S. Carcinogenesis mechanisms of Fusobacterium nucleatum. Biomed. Pharmacother. 2017, 89, 918-925. [CrossRef]

191. Kostic, A.D.; Chun, E.; Robertson, L.; Glickman, J.N.; Gallini, C.A.; Michaud, M.; Clancy, T.E.; Chung, D.C.; Lochhead, P.; Hold, G.L.; et al. Fusobacterium nucleatum potentiates intestinal tumorigenesis and modulates the tumor-immune microenvironment. Cell Host Microbe 2013, 14, 207-215. [CrossRef] [PubMed]

192. Nakatsu, G.; Li, X.; Zhou, H.; Sheng, J.; Wong, S.H.; Wu, W.K.; Ng, S.C.; Tsoi, H.; Dong, Y.; Zhang, N.; et al. Gut mucosal microbiome across stages of colorectal carcinogenesis. Nat. Commun. 2015, 6, 8727. [CrossRef]

193. Castellarin, M.; Warren, R.L.; Freeman, J.D.; Dreolini, L.; Krzywinski, M.; Strauss, J.; Barnes, R.; Watson, P.; Allen-Vercoe, E.; Moore, R.A.; et al. Fusobacterium nucleatum infection is prevalent in human colorectal carcinoma. Genome Res. 2012, 22, 299-306. [CrossRef] [PubMed]

194. Kostic, A.D.; Gevers, D.; Pedamallu, C.S.; Michaud, M.; Duke, F.; Earl, A.M.; Ojesina, A.I.; Jung, J.; Bass, A.J.; Tabernero, J.; et al. Genomic analysis identifies association of Fusobacterium with colorectal carcinoma. Genome Res. 2012, 22, 292-298. [CrossRef]

195. Zhou, Z.; Chen, J.; Yao, H.; Hu, H. Fusobacterium and Colorectal Cancer. Front. Oncol. 2018, 8, 371. [CrossRef] [PubMed]

196. Gur, C.; Ibrahim, Y.; Isaacson, B.; Yamin, R.; Abed, J.; Gamliel, M.; Enk, J.; Bar-On, Y.; Stanietsky-Kaynan, N.; Coppenhagen-Glazer, S.; et al. Binding of the Fap2 protein of Fusobacterium nucleatum to human inhibitory receptor TIGIT protects tumors from immune cell attack. Immunity 2015, 42, 344-355. [CrossRef] [PubMed]

197. Rubinstein, M.R.; Baik, J.E.; Lagana, S.M.; Han, R.P.; Raab, W.J.; Sahoo, D.; Dalerba, P.; Wang, T.C.; Han, Y.W. Fusobacterium nucleatum promotes colorectal cancer by inducing Wnt/beta-catenin modulator Annexin A1. EMBO Rep. 2019, 20. [CrossRef] 
198. Yan, X.; Liu, L.; Li, H.; Qin, H.; Sun, Z. Clinical significance of Fusobacterium nucleatum, epithelial-mesenchymal transition, and cancer stem cell markers in stage III/IV colorectal cancer patients. Onco Targets Ther. 2017, 10, 5031-5046. [CrossRef]

199. Ma, C.T.; Luo, H.S.; Gao, F.; Tang, Q.C.; Chen, W. Fusobacterium nucleatum promotes the progression of colorectal cancer by interacting with E-cadherin. Oncol. Lett. 2018, 16, 2606-2612. [CrossRef]

200. Bullman, S.; Pedamallu, C.S.; Sicinska, E.; Clancy, T.E.; Zhang, X.; Cai, D.; Neuberg, D.; Huang, K.; Guevara, F.; Nelson, T.; et al Analysis of Fusobacterium persistence and antibiotic response in colorectal cancer. Science 2017, 358, 1443-1448. [CrossRef]

201. Yu, T.; Guo, F.; Yu, Y.; Sun, T.; Ma, D.; Han, J.; Qian, Y.; Kryczek, I.; Sun, D.; Nagarsheth, N.; et al. Fusobacterium nucleatum Promotes Chemoresistance to Colorectal Cancer by Modulating Autophagy. Cell 2017, 170, 548-563.e516. [CrossRef]

202. Mima, K.; Nishihara, R.; Qian, Z.R.; Cao, Y.; Sukawa, Y.; Nowak, J.A.; Yang, J.; Dou, R.; Masugi, Y.; Song, M.; et al. Fusobacterium nucleatum in colorectal carcinoma tissue and patient prognosis. Gut 2016, 65, 1973-1980. [CrossRef]

203. Hamada, T.; Zhang, X.; Mima, K.; Bullman, S.; Sukawa, Y.; Nowak, J.A.; Kosumi, K.; Masugi, Y.; Twombly, T.S.; Cao, Y.; et al. Fusobacterium nucleatum in Colorectal Cancer Relates to Immune Response Differentially by Tumor Microsatellite Instability Status. Cancer Immunol. Res. 2018, 6, 1327-1336. [CrossRef] [PubMed]

204. Tahara, T.; Yamamoto, E.; Suzuki, H.; Maruyama, R.; Chung, W.; Garriga, J.; Jelinek, J.; Yamano, H.O.; Sugai, T.; An, B.; et al. Fusobacterium in colonic flora and molecular features of colorectal carcinoma. Cancer Res. 2014, 74, 1311-1318. [CrossRef] [PubMed]

205. Ito, M.; Kanno, S.; Nosho, K.; Sukawa, Y.; Mitsuhashi, K.; Kurihara, H.; Igarashi, H.; Takahashi, T.; Tachibana, M.; Takahashi, H.; et al. Association of Fusobacterium nucleatum with clinical and molecular features in colorectal serrated pathway. Int. J. Cancer 2015, 137, 1258-1268. [CrossRef]

206. De Angelis, G.L.; Bottarelli, L.; Azzoni, C.; De Angelis, N.; Leandro, G.; Di Mario, F.; Gaiani, F.; Negri, F. Microsatellite instability in colorectal cancer. Acta Biomed. 2018, 89, 97-101. [CrossRef]

207. Serna, G.; Ruiz-Pace, F.; Hernando, J.; Alonso, L.; Fasani, R.; Landolfi, S.; Comas, R.; Jimenez, J.; Elez, E.; Bullman, S.; et al. Fusobacterium nucleatum persistence and risk of recurrence after preoperative treatment in locally advanced rectal cancer. Ann. Oncol. 2020, 31, 1366-1375. [CrossRef] [PubMed]

208. Yi, Y.; Shen, L.; Shi, W.; Xia, F.; Zhang, H.; Wang, Y.; Zhang, J.; Wang, Y.; Sun, X.; Zhang, Z.; et al. Gut Microbiome Components Predict Response to Neoadjuvant Chemoradiotherapy in Patients with Locally Advanced Rectal Cancer: A Prospective, Longitudinal Study. Clin. Cancer Res. 2021, 27, 1329-1340. [CrossRef]

209. Kattan, M.W.; Hess, K.R.; Amin, M.B.; Lu, Y.; Moons, K.G.; Gershenwald, J.E.; Gimotty, P.A.; Guinney, J.H.; Halabi, S.; Lazar, A.J.; et al. American Joint Committee on Cancer acceptance criteria for inclusion of risk models for individualized prognosis in the practice of precision medicine. CA Cancer J. Clin. 2016, 66, 370-374. [CrossRef]

210. Asare, E.A.; Washington, M.K.; Gress, D.M.; Gershenwald, J.E.; Greene, F.L. Improving the quality of cancer staging. CA Cancer J. Clin. 2015, 65, 261-263. [CrossRef]

211. Reilly, B.M.; Evans, A.T. Translating clinical research into clinical practice: Impact of using prediction rules to make decisions. Ann. Intern. Med. 2006, 144, 201-209. [CrossRef]

212. Gervasoni, J.E., Jr.; Sbayi, S.; Cady, B. Role of lymphadenectomy in surgical treatment of solid tumors: An update on the clinical data. Ann. Surg. Oncol. 2007, 14, 2443-2462. [CrossRef]

213. Cady, B. Lymph node metastases. Indicators, but not governors of survival. Arch. Surg. 1984, 119, 1067-1072. [CrossRef] [PubMed]

214. Gill, S.; Loprinzi, C.L.; Sargent, D.J.; Thome, S.D.; Alberts, S.R.; Haller, D.G.; Benedetti, J.; Francini, G.; Shepherd, L.E.; Francois Seitz, J.; et al. Pooled analysis of fluorouracil-based adjuvant therapy for stage II and III colon cancer: Who benefits and by how much? J. Clin. Oncol. 2004, 22, 1797-1806. [CrossRef]

215. Gunderson, L.L.; Jessup, J.M.; Sargent, D.J.; Greene, F.L.; Stewart, A. Revised tumor and node categorization for rectal cancer based on surveillance, epidemiology, and end results and rectal pooled analysis outcomes. J. Clin. Oncol. 2010, 28, 256-263. [CrossRef]

216. Sobrero, A.F.; Puccini, A.; Shi, Q.; Grothey, A.; Andre, T.; Shields, A.F.; Souglakos, I.; Yoshino, T.; Iveson, T.; Ceppi, M.; et al. A new prognostic and predictive tool for shared decision making in stage III colon cancer. Eur. J. Cancer 2020, 138, 182-188. [CrossRef]

217. Weinberg, R.A. Mechanisms of malignant progression. Carcinogenesis 2008, 29, 1092-1095. [CrossRef]

218. Campbell, P.J.; Yachida, S.; Mudie, L.J.; Stephens, P.J.; Pleasance, E.D.; Stebbings, L.A.; Morsberger, L.A.; Latimer, C.; McLaren, S.; Lin, M.L.; et al. The patterns and dynamics of genomic instability in metastatic pancreatic cancer. Nature 2010, 467, 1109-1113. [CrossRef]

219. Yachida, S.; Jones, S.; Bozic, I.; Antal, T.; Leary, R.; Fu, B.; Kamiyama, M.; Hruban, R.H.; Eshleman, J.R.; Nowak, M.A.; et al. Distant metastasis occurs late during the genetic evolution of pancreatic cancer. Nature 2010, 467, 1114-1117. [CrossRef]

220. Coghlin, C.; Murray, G.I. Current and emerging concepts in tumour metastasis. J. Pathol. 2010, 222, 1-15. [CrossRef] [PubMed]

221. Klein, C.A. Parallel progression of primary tumours and metastases. Nat. Rev. Cancer 2009, 9, 302-312. [CrossRef]

222. Gerhardt, H.; Semb, H. Pericytes: Gatekeepers in tumour cell metastasis? J. Mol. Med. 2008, 86, 135-144. [CrossRef]

223. Liu, W.; Laitinen, S.; Khan, S.; Vihinen, M.; Kowalski, J.; Yu, G.; Chen, L.; Ewing, C.M.; Eisenberger, M.A.; Carducci, M.A.; et al. Copy number analysis indicates monoclonal origin of lethal metastatic prostate cancer. Nat. Med. 2009, 15, 559-565. [CrossRef]

224. McPherson, A.; Roth, A.; Laks, E.; Masud, T.; Bashashati, A.; Zhang, A.W.; Ha, G.; Biele, J.; Yap, D.; Wan, A.; et al. Divergent modes of clonal spread and intraperitoneal mixing in high-grade serous ovarian cancer. Nat. Genet. 2016, 48, 758-767. [CrossRef] 
225. Gibson, W.J.; Hoivik, E.A.; Halle, M.K.; Taylor-Weiner, A.; Cherniack, A.D.; Berg, A.; Holst, F.; Zack, T.I.; Werner, H.M.; Staby, K.M.; et al. The genomic landscape and evolution of endometrial carcinoma progression and abdominopelvic metastasis. Nat. Genet. 2016, 48, 848-855. [CrossRef]

226. Reiter, J.G.; Makohon-Moore, A.P.; Gerold, J.M.; Bozic, I.; Chatterjee, K.; Iacobuzio-Donahue, C.A.; Vogelstein, B.; Nowak, M.A. Reconstructing metastatic seeding patterns of human cancers. Nat. Commun. 2017, 8, 14114. [CrossRef]

227. Haffner, M.C.; Mosbruger, T.; Esopi, D.M.; Fedor, H.; Heaphy, C.M.; Walker, D.A.; Adejola, N.; Gurel, M.; Hicks, J.; Meeker, A.K.; et al. Tracking the clonal origin of lethal prostate cancer. J. Clin. Investig. 2013, 123, 4918-4922. [CrossRef]

228. Naxerova, K.; Reiter, J.G.; Brachtel, E.; Lennerz, J.K.; van de Wetering, M.; Rowan, A.; Cai, T.; Clevers, H.; Swanton, C.; Nowak, M.A.; et al. Origins of lymphatic and distant metastases in human colorectal cancer. Science 2017, 357, 55-60. [CrossRef]

229. Talmadge, J.E.; Fidler, I.J. AACR centennial series: The biology of cancer metastasis: Historical perspective. Cancer Res. 2010, 70, 5649-5669. [CrossRef] [PubMed]

230. Montagut, C.; Dalmases, A.; Bellosillo, B.; Crespo, M.; Pairet, S.; Iglesias, M.; Salido, M.; Gallen, M.; Marsters, S.; Tsai, S.P.; et al. Identification of a mutation in the extracellular domain of the Epidermal Growth Factor Receptor conferring cetuximab resistance in colorectal cancer. Nat. Med. 2012, 18, 221-223. [CrossRef]

231. Parsons, B.L.; Myers, M.B. KRAS mutant tumor subpopulations can subvert durable responses to personalized cancer treatments. Per. Med. 2013, 10, 191-199. [CrossRef]

232. Coppe, J.P.; Patil, C.K.; Rodier, F.; Sun, Y.; Munoz, D.P.; Goldstein, J.; Nelson, P.S.; Desprez, P.Y.; Campisi, J. Senescence-associated secretory phenotypes reveal cell-nonautonomous functions of oncogenic RAS and the p53 tumor suppressor. PLoS Biol. 2008, 6, 2853-2868. [CrossRef]

233. Floor, S.L.; Dumont, J.E.; Maenhaut, C.; Raspe, E. Hallmarks of cancer: Of all cancer cells, all the time? Trends Mol. Med. 2012, 18, 509-515. [CrossRef] [PubMed]

234. Fidler, I.J.; Jessup, J.M.; Fogler, W.E.; Staerkel, R.; Mazumder, A. Activation of tumoricidal properties in peripheral blood monocytes of patients with colorectal carcinoma. Cancer Res. 1986, 46, 994-998.

235. Marusyk, A.; Almendro, V.; Polyak, K. Intra-tumour heterogeneity: A looking glass for cancer? Nat. Rev. Cancer 2012, 12, 323-334. [CrossRef]

236. Hunter, K.W.; Amin, R.; Deasy, S.; Ha, N.H.; Wakefield, L. Genetic insights into the morass of metastatic heterogeneity. Nat. Rev. Cancer 2018, 18, 211-223. [CrossRef]

237. Fischer, K.R.; Durrans, A.; Lee, S.; Sheng, J.; Li, F.; Wong, S.T.; Choi, H.; El Rayes, T.; Ryu, S.; Troeger, J.; et al. Epithelialto-mesenchymal transition is not required for lung metastasis but contributes to chemoresistance. Nature 2015, 527, $472-476$. [CrossRef]

238. Boral, D.; Vishnoi, M.; Liu, H.N.; Yin, W.; Sprouse, M.L.; Scamardo, A.; Hong, D.S.; Tan, T.Z.; Thiery, J.P.; Chang, J.C.; et al. Molecular characterization of breast cancer CTCs associated with brain metastasis. Nat. Commun. 2017, 8, 196. [CrossRef] [PubMed]

239. Naxerova, K.; Jain, R.K. Using tumour phylogenetics to identify the roots of metastasis in humans. Nat. Rev. Clin. Oncol. 2015, 12, 258-272. [CrossRef]

240. Robinson, D.R.; Wu, Y.M.; Lonigro, R.J.; Vats, P.; Cobain, E.; Everett, J.; Cao, X.; Rabban, E.; Kumar-Sinha, C.; Raymond, V.; et al. Integrative clinical genomics of metastatic cancer. Nature 2017, 548, 297-303. [CrossRef]

241. Fidler, I.J.; Nicolson, G.L. Fate of recirculating B16 melanoma metastatic variant cells in parabiotic syngeneic recipients. J. Natl. Cancer Inst. 1977, 58, 1867-1872. [CrossRef] [PubMed]

242. Welch, D.R. Tumor Heterogeneity-A ‘Contemporary Concept' Founded on Historical Insights and Predictions. Cancer Res. 2016, 76, 4-6. [CrossRef] [PubMed]

243. Ciardiello, F.; Arnold, D.; Casali, P.G.; Cervantes, A.; Douillard, J.Y.; Eggermont, A.; Eniu, A.; McGregor, K.; Peters, S.; Piccart, M.; et al. Delivering precision medicine in oncology today and in future-the promise and challenges of personalised cancer medicine: A position paper by the European Society for Medical Oncology (ESMO). Ann. Oncol. 2014, 25, 1673-1678. [CrossRef]

244. Engelman, J.A.; Zejnullahu, K.; Mitsudomi, T.; Song, Y.; Hyland, C.; Park, J.O.; Lindeman, N.; Gale, C.M.; Zhao, X.; Christensen, J.; et al. MET amplification leads to gefitinib resistance in lung cancer by activating ERBB3 signaling. Science 2007, 316, 1039-1043. [CrossRef]

245. Amado, R.G.; Wolf, M.; Peeters, M.; Van Cutsem, E.; Siena, S.; Freeman, D.J.; Juan, T.; Sikorski, R.; Suggs, S.; Radinsky, R.; et al. Wild-type KRAS is required for panitumumab efficacy in patients with metastatic colorectal cancer. J. Clin. Oncol. 2008, 26, 1626-1634. [CrossRef]

246. Bardelli, A.; Corso, S.; Bertotti, A.; Hobor, S.; Valtorta, E.; Siravegna, G.; Sartore-Bianchi, A.; Scala, E.; Cassingena, A.; Zecchin, D.; et al. Amplification of the MET receptor drives resistance to anti-EGFR therapies in colorectal cancer. Cancer Discov. 2013, 3, 658-673. [CrossRef]

247. Inno, A.; Di Salvatore, M.; Cenci, T.; Martini, M.; Orlandi, A.; Strippoli, A.; Ferrara, A.M.; Bagala, C.; Cassano, A.; Larocca, L.M.; et al. Is there a role for IGF1R and c-MET pathways in resistance to cetuximab in metastatic colorectal cancer? Clin. Colorectal. Cancer 2011, 10, 325-332. [CrossRef]

248. Karadima, M.L.; Saetta, A.A.; Chatziandreou, I.; Lazaris, A.C.; Patsouris, E.; Tsavaris, N. The Prognostic Influence of BRAF Mutation and other Molecular, Clinical and Laboratory Parameters in Stage IV Colorectal Cancer. Pathol. Oncol. Res. 2016, 22, 707-714. [CrossRef] [PubMed] 
249. Rowland, A.; Dias, M.M.; Wiese, M.D.; Kichenadasse, G.; McKinnon, R.A.; Karapetis, C.S.; Sorich, M.J. Meta-analysis comparing the efficacy of anti-EGFR monoclonal antibody therapy between KRAS G13D and other KRAS mutant metastatic colorectal cancer tumours. Eur. J. Cancer 2016, 55, 122-130. [CrossRef]

250. Turke, A.B.; Zejnullahu, K.; Wu, Y.L.; Song, Y.; Dias-Santagata, D.; Lifshits, E.; Toschi, L.; Rogers, A.; Mok, T.; Sequist, L.; et al. Preexistence and clonal selection of MET amplification in EGFR mutant NSCLC. Cancer Cell 2010, 17, 77-88. [CrossRef]

251. Yonesaka, K.; Zejnullahu, K.; Okamoto, I.; Satoh, T.; Cappuzzo, F.; Souglakos, J.; Ercan, D.; Rogers, A.; Roncalli, M.; Takeda, M.; et al. Activation of ERBB2 signaling causes resistance to the EGFR-directed therapeutic antibody cetuximab. Sci. Transl. Med. 2011, 3, 99ra86. [CrossRef] [PubMed]

252. Knijn, N.; Mekenkamp, L.J.; Klomp, M.; Vink-Borger, M.E.; Tol, J.; Teerenstra, S.; Meijer, J.W.; Tebar, M.; Riemersma, S.; van Krieken, J.H.; et al. KRAS mutation analysis: A comparison between primary tumours and matched liver metastases in 305 colorectal cancer patients. Br. J. Cancer 2011, 104, 1020-1026. [CrossRef]

253. Misale, S.; Di Nicolantonio, F.; Sartore-Bianchi, A.; Siena, S.; Bardelli, A. Resistance to anti-EGFR therapy in colorectal cancer: From heterogeneity to convergent evolution. Cancer Discov. 2014, 4, 1269-1280. [CrossRef] [PubMed]

254. Diaz, L.A., Jr.; Williams, R.T.; Wu, J.; Kinde, I.; Hecht, J.R.; Berlin, J.; Allen, B.; Bozic, I.; Reiter, J.G.; Nowak, M.A.; et al. The molecular evolution of acquired resistance to targeted EGFR blockade in colorectal cancers. Nature 2012, 486, 537-540. [CrossRef] [PubMed]

255. Misale, S.; Yaeger, R.; Hobor, S.; Scala, E.; Janakiraman, M.; Liska, D.; Valtorta, E.; Schiavo, R.; Buscarino, M.; Siravegna, G.; et al. Emergence of KRAS mutations and acquired resistance to anti-EGFR therapy in colorectal cancer. Nature 2012, 486, 532-536. [CrossRef]

256. Siravegna, G.; Mussolin, B.; Buscarino, M.; Corti, G.; Cassingena, A.; Crisafulli, G.; Ponzetti, A.; Cremolini, C.; Amatu, A.; Lauricella, C.; et al. Clonal evolution and resistance to EGFR blockade in the blood of colorectal cancer patients. Nat. Med. 2015, 21, 827. [CrossRef] [PubMed]

257. Arena, S.; Bellosillo, B.; Siravegna, G.; Martinez, A.; Canadas, I.; Lazzari, L.; Ferruz, N.; Russo, M.; Misale, S.; Gonzalez, I.; et al. Emergence of Multiple EGFR Extracellular Mutations during Cetuximab Treatment in Colorectal Cancer. Clin. Cancer Res. 2015, 21, 2157-2166. [CrossRef]

258. Hata, A.; Katakami, N.; Fujita, S.; Takatori, K.; Horai, A.; Kitajima, N.; Terashima, K. Panitumumab rechallenge in chemorefractory patients with metastatic colorectal cancer. J. Gastrointest Cancer 2013, 44, 456-459. [CrossRef]

259. Russo, M.; Crisafulli, G.; Sogari, A.; Reilly, N.M.; Arena, S.; Lamba, S.; Bartolini, A.; Amodio, V.; Magri, A.; Novara, L.; et al. Adaptive mutability of colorectal cancers in response to targeted therapies. Science 2019, 366, 1473-1480. [CrossRef]

260. Troiani, T.; Martinelli, E.; Napolitano, S.; Vitagliano, D.; Ciuffreda, L.P.; Costantino, S.; Morgillo, F.; Capasso, A.; Sforza, V.; Nappi, A.; et al. Increased TGF-alpha as a mechanism of acquired resistance to the anti-EGFR inhibitor cetuximab through EGFR-MET interaction and activation of MET signaling in colon cancer cells. Clin. Cancer Res. 2013, 19, 6751-6765. [CrossRef]

261. Troiani, T.; Napolitano, S.; Vitagliano, D.; Morgillo, F.; Capasso, A.; Sforza, V.; Nappi, A.; Ciardiello, D.; Ciardiello, F.; Martinelli, E. Primary and acquired resistance of colorectal cancer cells to anti-EGFR antibodies converge on MEK/ERK pathway activation and can be overcome by combined MEK/EGFR inhibition. Clin. Cancer Res. 2014, 20, 3775-3786. [CrossRef]

262. Russo, M.; Di Nicolantonio, F.; Bardelli, A. Climbing RAS, the everest of oncogenes. Cancer Discov. 2014, 4, 19-21. [CrossRef]

263. Ciardiello, F.; Bianco, R.; Caputo, R.; Caputo, R.; Damiano, V.; Troiani, T.; Melisi, D.; De Vita, F.; De Placido, S.; Bianco, A.R.; et al. Antitumor activity of ZD6474, a vascular endothelial growth factor receptor tyrosine kinase inhibitor, in human cancer cells with acquired resistance to antiepidermal growth factor receptor therapy. Clin. Cancer Res. 2004, 10, 784-793. [CrossRef]

264. Santini, D.; Vincenzi, B.; Addeo, R.; Garufi, C.; Masi, G.; Scartozzi, M.; Mancuso, A.; Frezza, A.M.; Venditti, O.; Imperatori, M.; et al. Cetuximab rechallenge in metastatic colorectal cancer patients: How to come away from acquired resistance? Ann. Oncol. 2012, 23, 2313-2318. [CrossRef]

265. Yancopoulos, G.D.; Davis, S.; Gale, N.W.; Rudge, J.S.; Wiegand, S.J.; Holash, J. Vascular-specific growth factors and blood vessel formation. Nature 2000, 407, 242-248. [CrossRef]

266. Grothey, A.; Van Cutsem, E.; Sobrero, A.; Siena, S.; Falcone, A.; Ychou, M.; Humblet, Y.; Bouche, O.; Mineur, L.; Barone, C.; et al. Regorafenib monotherapy for previously treated metastatic colorectal cancer (CORRECT): An international, multicentre, randomised, placebo-controlled, phase 3 trial. Lancet 2013, 381, 303-312. [CrossRef]

267. Wilhelm, S.M.; Dumas, J.; Adnane, L.; Lynch, M.; Carter, C.A.; Schutz, G.; Thierauch, K.H.; Zopf, D. Regorafenib (BAY 73-4506): A new oral multikinase inhibitor of angiogenic, stromal and oncogenic receptor tyrosine kinases with potent preclinical antitumor activity. Int. J. Cancer 2011, 129, 245-255. [CrossRef]

268. Tsai, J.H.; Lee, W.M. Tie2 in tumor endothelial signaling and survival: Implications for antiangiogenic therapy. Mol. Cancer Res. 2009, 7, 300-310. [CrossRef]

269. Schmieder, R.; Hoffmann, J.; Becker, M.; Bhargava, A.; Muller, T.; Kahmann, N.; Ellinghaus, P.; Adams, R.; Rosenthal, A.; Thierauch, K.H.; et al. Regorafenib (BAY 73-4506): Antitumor and antimetastatic activities in preclinical models of colorectal cancer. Int. J. Cancer 2014, 135, 1487-1496. [CrossRef]

270. Napolitano, S.; Martini, G.; Rinaldi, B.; Martinelli, E.; Donniacuo, M.; Berrino, L.; Vitagliano, D.; Morgillo, F.; Barra, G.; De Palma, R.; et al. Primary and Acquired Resistance of Colorectal Cancer to Anti-EGFR Monoclonal Antibody Can Be Overcome by Combined Treatment of Regorafenib with Cetuximab. Clin. Cancer Res. 2015, 21, 2975-2983. [CrossRef] 
271. Shitara, K.; Yamanaka, T.; Denda, T.; Tsuji, Y.; Shinozaki, K.; Komatsu, Y.; Kobayashi, Y.; Furuse, J.; Okuda, H.; Asayama, M.; et al. REVERCE: A randomized phase II study of regorafenib followed by cetuximab versus the reverse sequence for previously treated metastatic colorectal cancer patients. Ann. Oncol. 2019, 30, 259-265. [CrossRef] [PubMed]

272. Takegawa, N.; Yonesaka, K.; Sakai, K.; Ueda, H.; Watanabe, S.; Nonagase, Y.; Okuno, T.; Takeda, M.; Maenishi, O.; Tsurutani, J.; et al. HER2 genomic amplification in circulating tumor DNA from patients with cetuximab-resistant colorectal cancer. Oncotarget 2016, 7, 3453-3460. [CrossRef] [PubMed]

273. Pietrantonio, F.; Vernieri, C.; Siravegna, G.; Mennitto, A.; Berenato, R.; Perrone, F.; Gloghini, A.; Tamborini, E.; Lonardi, S.; Morano, F; et al. Heterogeneity of Acquired Resistance to Anti-EGFR Monoclonal Antibodies in Patients with Metastatic Colorectal Cancer. Clin. Cancer Res. 2017, 23, 2414-2422. [CrossRef] [PubMed]

274. Khan, K.H.; Cunningham, D.; Werner, B.; Vlachogiannis, G.; Spiteri, I.; Heide, T.; Mateos, J.F.; Vatsiou, A.; Lampis, A.; Damavandi, M.D.; et al. Longitudinal Liquid Biopsy and Mathematical Modeling of Clonal Evolution Forecast Time to Treatment Failure in the PROSPECT-C Phase II Colorectal Cancer Clinical Trial. Cancer Discov. 2018, 8, 1270-1285. [CrossRef]

275. Beaver, J.A.; Jelovac, D.; Balukrishna, S.; Cochran, R.; Croessmann, S.; Zabransky, D.J.; Wong, H.Y.; Toro, P.V.; Cidado, J.; Blair, B.G.; et al. Detection of cancer DNA in plasma of patients with early-stage breast cancer. Clin. Cancer Res. 2014, 20, 2643-2650. [CrossRef] 